\title{
Shaped for beauty \\ Vocational and gendered subjectivities in private education for the beauty industry
}

\author{
Eleonor Bredlöv
}

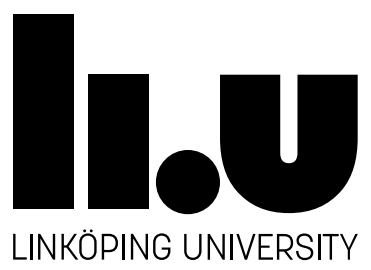

Linköping Studies in Behavioural Science No. 209

Faculty of Educational Sciences

Linköping 2018 
Linköping Studies in Behavioural Science • No. 209

Distributed by:

Department of Behavioural Sciences and Learning

Linköping University

SE-581 83 Linköping

Eleonor Bredlöv

Shaped for Beauty

Vocational and gendered subjectivities in private education for the beauty industry

Edition 1:1

ISBN 978-91-7685-248-4

ISSN 1654-2029

C)Eleonor Bredlöv

Department of Behavioural Sciences and Learning, 2018

Cover by: Malin Wallin

Printed by: LiU-Tryck, Linköping 2018 


\section{Förord}

Churchill (?!) lär ha sagt något i stil med: “Går du igenom ett helvete, fortsätt för allt i världen att gå”. Han kanske syftade på andra saker än att skriva en avhandling i pedagogik, men för doktoranden själv kan detta vara nog så skräckfyllt och ibland te sig helt omöjligt. I sådana perioder är det avgörande att ha människor omkring sig, både inom och utanför akademin, som på olika sätt kan ge en perspektiv och vägledning så att man kommer vidare och kan fortsätta gå; meddoktorander, kollegor, vänner och familj. Er vill jag tacka nu när det tillslut är över.

I synnerhet vill jag tacka mina handledare som varit delaktiga i detta avhandlingsprojekts framväxt och hjälpt mig att smalna av, fokusera och fördjupa. Andreas Fejes, min huvudhandledare, som med sin förmåga att identifiera väsentligheter, spetsa till argument och snabbt se den mest effektiva vägen framåt, varit ovärderlig för min lärandeprocess och bidragit med tydlig vägledning, kreativa diskussioner, och analytisk skärpa. Jag har även Andreas att tacka för att mina texter nu eventuellt kan passera som "Foucault-inspirerade”. Jag vill också tacka Susanne Köpsén, som varit min bihandledare, för hennes allomfattande kunnande inom yrkesforskning, hennes engagemang och kluriga frågor. Susanne var även viktig när jag i start-skedet skulle definiera mitt forskningsfält. Ett Stort tack till er båda!

Jag har också haft turen att ha andra professionella, skarpa, konstruktiva och kritiskt sinnade kollegor som läst, kommenterat och diskuterat mina texter, främst på forskningsseminarier, men också i forskarutbildningskurser och inom ramen för den Nationella forskarskolan i yrkesdidaktik. Detta har varit så otroligt värdefullt! Ett särskilt tack till Ulf Olsson som granskade mitt 60\%-manus, och Kerstin Sandell, granskare av mitt 90\%-manus, som båda gjorde noggranna läsningar och gav mig nya frågor att fundera över, och blåste liv i gamla. Tack också till Katarina Eriksson Barajas, som i egenskap av läsgruppsmedlem läste och klokt kommenterade min text inför det absoluta slutskedet.

Mina kollegor på Pedvux - jag är så glad för att ha haft en så omtänksam, proffsig och stärkande arbetsgrupp omkring mig. Alla givande och intellektuellt stimulerande diskussioner vi haft under avdelningens forskningsseminarier, eller över ännu ett av Song-ees underbara bakverk, alla skratt och alla erfarenheter som vi delat - så fint att vara en del av detta! Och alla fantastiska doktorandkollegor, inom och utom avdelningen, som delat mina plågor och funderingar och peppat mig när jag behövt det som mest. Sofia som ständigt diskuterat forskningens vara eller icke-vara med mig, där vi vridit och vänt på vår praktik och teori. Så viktigt och bra! Och Lina, som tillsammans med mig och ett gäng fenomenala doktorander drivit tidskriften Confero, din vishet visar inga gränser! Och så Camilla förstås, min kloka vän och kollega, vad skulle JAG göra utan dig? Hade aldrig gått. Tack så mycket allesammans! 
Jag vill också rikta ett Stort tack till de kursdeltagare som lät sig bli intervjuade, och som generöst nog lät mig smyga omkring i deras klassrum och observera deras förehavanden, och till de lärare och rektorer som välkomnade mig till sina arbetsplatser. Utan er hade det knappast blivit någon avhandling.

Tack också till vänner och familj, för att ni finns, är så fina och ger perspektiv på tillvaron. Ett särskilt tack till min mamma, Britt, som med sin hök-blick gick igenom och korrade mina referenser, och till pappa, Lars, som hjälpte till. Och ett Stort tack till er båda för ert osvikliga stöd och er uppmuntran genom alla mina studier. Ett särskilt tack också till min svägerska och vän Malin Wallin som gjorde illustrationerna till denna boks omslag - du är ett geni!

Slutligen, tack till min underbara lilla familj; Jakob för all kärlek och alla skratt, ditt osvikliga tålamod och uppmuntrande ord gällande den fjärde familjemedlemmen - Avhandlingen - och vår lille Otis förstås, för att du är du.

Ireviken, Juli 2018

Eleonor Bredlöv 


\section{CONTENTS}

$\begin{array}{ll}\text { LIST OF PAPERS } & 7\end{array}$

INTRODUCTION 9

$\begin{array}{lr}\text { ORGANIZATION OF VET IN SWEDEN } & 10\end{array}$

THE BEAUTY INDUSTRY AND ITS EDUCATIONAL SPHERE

The beauty industry 12

Beauty education 14

$\begin{array}{ll}\text { PREVIOUS RESEARCH } & 17\end{array}$

GENDER IN VET 17

Gender segregation 18

Gendered processes of becoming in VET 19

GENDERED KNOWLEDGE IN VET 20

Emotional labour $\quad 21$

Caring knowledge 23

CONCLUDING REMARKS

$\begin{array}{ll}\text { THEORIZATION } & 27\end{array}$

$\begin{array}{ll}\text { A PRODUCTIVE CONCEPT OF POWER } & 28\end{array}$

DISCOURSE AND DISCURSIVE PRACTICES

THE PRODUCTION OF SUBJECTIVITIES

CONCLUDING REMARKS

AIM AND RESEARCH QUESTIONS 37

METHODOLOGICAL APPROACH 38

$\begin{array}{lr}\text { RECRUITMENT MATERIAL } & 39\end{array}$

ACCESS 40

INITIAL FIELDWORK $\quad 40$

SEMI-STRUCTURED INTERVIEWS

Participants $\quad 42$

Interviews 43

OBSERVATIONS

Practical lessons $\quad 45$

Performing the observations 46

$\begin{array}{ll}\text { SCOPE OF MATERIAL } & 47\end{array}$

$\begin{array}{ll}\text { ETHICAL CONSIDERATIONS } & 47\end{array}$

ANALYTICAL APPROACH $\quad 49$

Regularities $\quad 50$

Data analysis $\quad 51$

REFLEXIVITY OF THE RESEARCHER

QUALITY AND TRUSTWORTHINESS

SUMMARIES

DISCUSSION

RESULTS REVISITED $\quad 62$

DOMINANT DISCOURSES OF SCIENCE AND EXCLUDED KNOWLEDGES 65 
UNPREDICTED ASPECTS OF BEAUTY IDEALS

REFERENCES

74

APPENDIX: INTERVIEW GUIDE 


\section{LIST OF PAPERS}

I. Bredlöv, E. (2016). Shaping the female student. An analysis of Swedish beauty school recruitment texts. Studies in Continuing Education, 38(2): 243-258.

II. Bredlöv, E. (2016). Constructing a professional. Gendered knowledge in the (self-)positioning of skin and spa therapy students, Gender \& Education, 29(7): 890-906.

III. Linder Eknor, E. (2017). Learning a critical gaze. Producing gendered bodies in skin and spa therapy education and training, Journal of Vocational Education and Training, https://doi.org/10.1080/13636820.2017.1394354

IV. Bredlöv Eknor, E. Becoming an emotional worker and student. Exploring skin and spa therapy education and training. Submitted to Studies in Continuing Education. 


\title{
INTRODUCTION
}

\begin{abstract}
Interviewer: What do you think characterizes a successful skin therapist or spa therapist? What should one be like?

Diana (a student): One should be calm/peaceful and harmonic, one should have positive energy that you can pass on to the client, have knowledge about the body, the products, the treatments. You should be able to explain things to the client so that the client understands, be caring and nice and polite. (Interview no. 12)
\end{abstract}

Sandra (a student): (...) You should be self-confident, you should be like a ballerina.

Interviewer: What should one be like then?

Sandra: You should stand up straight, sit up straight when you're performing treatments or walking. You should be well groomed, have light natural makeup with your hair up in a bun, with short nails since we are working with the skin and performing massages. (Interview no. 4)

Mary (a student): What we are trying to do is to receive the client from when they enter the door, like "welcome", and you should look like this (refers to her own appearance and the appearances of her fellow classmates). You should not have some sloppy updo and no makeup and say like "Uh hey, now you're going to get a facial treatment” (she says with a hasty, dark voice) - I mean then you are just destroying the experience for the client, you should be more like "Now you're here and I'm going to take care of you" (she says slowly with a calm, peaceful and light voice). (Interview no. 10)

Diana, Sandra and Mary are three students training to become skin and spa therapists. Here, they describe how one should be, look and act as a successful professional in the skin and spa therapy field. They talk a lot about the importance of appearance - how one should appear well-groomed, naturally feminine with light makeup, have well-manicured but natural looking nails and wear one's hair up in a bun. This feminine, harmonic and ballerina-like appearance should also be reflected in one's movements and behaviour, where walking and talking softly and calmly, with a straight posture, is the norm. Together with these ways of presenting oneself, one should also be competent at taking care of people, making them feel comfortable and cared for, shedding light and warmth in their lives. After training to become a skin and spa therapist, the students will work in a fast-growing and changeable industry and labour market, performing and promoting treatments and products, making them desirable for clients; selling a relaxing experience but also effective skin care. This is emotional and low status work, the salaries are poor and often commissionbased, and part-time employment is not unusual. This labour market is also characterized by an almost total dominance of women, which makes the beauty industry a distinct example of severe gender segregation.

Thereby, beauty education is aimed at educating workers that can adapt and fit into the gender-segregated environment of the beauty industry labour market. It is thus important to understand if and how a vocational educational 
and training (VET) context such as this might reproduce and reinforce gendered processes of becoming. ${ }^{1}$ This is important not least as gendered processes of (self-)selection have been argued to be particularly strong when it comes to VET, since there is a clearer linkage between VET and occupational identities than in the case of academic studies (Kupfer, 2014; Niemeyer \& Colley, 2015). Through doings and speakings in vocational VET, particular subjectivities are produced to fulfil a role - a function - in the labour market. Students are here educated to become professional workers in this labour market of gender division, and they are prepared for particular roles in society. These processes are thus gendered, which for example entails how knowledge is performed and valued and how professional status is produced.

The extensive gender segregation in the labour market is well known, but more knowledge is required to understand how such segregation is enacted, and maybe also reinforced, through educational arrangements. How does one become a professional with a purpose of working in a labour market that happens to be strongly segregated by gender? There are extensive processes of becoming in VET arrangements, processes that are gendered and that connect to contemporary circumstances in the labour market. However, these processes are not possible to discern only by taking a glance at the curriculums - closer empirical studies are needed. Gendered processes of becoming are distinct not least if we turn to VET specializations that are especially gender-specific, such as caring, construction, engineering and beauty work. Therefore, it is especially interesting and relevant to scrutinize processes of becoming in strongly gendered VET settings. One such setting is education and training for the beauty industry, which is the focus in this dissertation where I explore how students become professionals and how gender is at play throughout these processes. To understand how the educational field of the beauty industry can be placed in the VET field, the organization of VET in Sweden will be briefly outlined in the following, after which the beauty industry and its educational field will be described more thoroughly.

\section{Organization of VET in Sweden}

VET in Sweden is organized in three ways: VET programmes at upper secondary school, VET at post-secondary level called higher vocational education (HVE), and VET in the private sphere. These various ways of organizing VET differ in level of education, target group and regulatory framework. One of the key differences between different programmes and courses in all these three ways of organizing VET is, however, the gender representation. VET at upper secondary school is for example divided into twelve programmes - arrangements that feature extensive gender segregation. The gender representation in the twelve

1 'Processes of becoming in VET' refer to how learning of a vocation involves processes of becoming. Here, scholars have acknowledged the relationship between learning and identity, and how learning and vocational cultures transform the people taking part in them (see e.g. Colley, James, Diment \& Tedder, 2003). 
vocational programmes from the school year 2017/2018 is listed below (Swedish National Agency for Education, 2018):

\begin{tabular}{|l|l|l|}
\hline Programme: & Female: & Male: \\
\hline Child and Recreation & $60 \%$ & $40 \%$ \\
\hline Building and Construction & $9 \%$ & $91 \%$ \\
\hline Electricity and Energy & $3 \%$ & $97 \%$ \\
\hline Vehicle and Transport & $17 \%$ & $83 \%$ \\
\hline Business and Administration & $54 \%$ & $46 \%$ \\
\hline Handicraft & $94 \%$ & $6 \%$ \\
\hline Hotel and Tourism & $77 \%$ & $13 \%$ \\
\hline Industrial Technology & $12 \%$ & $88 \%$ \\
\hline Natural Resource Use & $68 \%$ & $32 \%$ \\
\hline $\begin{array}{l}\text { Restaurant Management and } \\
\text { Food }\end{array}$ & $54 \%$ & $46 \%$ \\
\hline $\begin{array}{l}\text { HVAC and Property } \\
\text { Maintenance }\end{array}$ & $3 \%$ & $97 \%$ \\
\hline Health and Social Care & $79 \%$ & $21 \%$ \\
\hline
\end{tabular}

Here, we can see that at least eight of these programmes are strongly segregated by gender, "HVAC and Property Maintenance" and "Electricity and Energy" being the most extreme cases. In the case of HVE, statistics from 2017 also show an unequal distribution of men and women across the vocational fields here; there were between $76 \%$ and $91 \%$ women in the fields "Economy, Administration and Sales", "Hotel, Restaurant Management and Tourism” and "Health and Social Services", and between $74 \%$ and $80 \%$ men in the fields "Civil Engineering and Building Technology", “Computers/IT” and “Technology and Manufacturing” (Swedish National Agency for Higher Vocational Education, 2018, p. 16). Statistics about gender representation are more difficult to obtain regarding VET in the private sphere; women, however, distinctly dominate beauty education.

The largest part of the VET arrangements is placed within upper secondary education. Participation here is free, and it is possible for young people to attend after completing compulsory school. More than $99 \%$ start, even though it is not mandatory, and about $27 \%$ chose to attend a vocational programme in 2017. ${ }^{3}$ Adults lacking grades at upper secondary level can participate in these programmes for free and with the possibility to apply for financial aid. ${ }^{4}$ The upper secondary school system has been a subject of debate, partly since structures based on class, gender and ethnicity emerge when looking at students' choices (see e.g. Hertzberg, 2007; Sandell, 2007) and education policy (see e.g. Carlbaum, 2011, 2012). Research has been conducted in relation to the more distinctly gender-divided programmes (Berglund, 2009; Gåfvels, 2016; Klope, 2015;), and some take gender into account (Ambjörnsson, 2004; Högberg, 2009; Nyström, 2012). The other two types of VET arrangements -

\footnotetext{
${ }^{2}$ HVAC stands for heating, ventilation and air conditioning.
} 
HVE and VET in the private sphere - have, however, been explored to a lesser extent.

HVE is available for adults who have completed upper secondary school, and is also free of charge and participants have the possibility of receiving financial aid. These educational programmes are offered on the basis of current labour market demand for competence. The Swedish National Agency for Education is responsible for analysing where in the labour market there is explicit demand for qualified workers, decide which vocational programmes are to be provided within HVE and allocate funding to education providers. Even if actors in the labour market have some influence, this agency makes all decisions concerning HVE.

When it comes to VET arrangements in the private sphere, the economic sectors are highly involved in making these arrangements. Trade organizations, school staff, business owners and other actors/stakeholders within the industry such as spa facilities and product brands often overlap when it comes to the people involved. Schools also always cooperate with a trade organization and different profit-making stakeholders in the industry. The economic sector of the beauty industry thereby has a great influence over the VET sphere, including how the students are to be formed for their future job roles. It is therefore particularly interesting to explore how students here are formed in vocational subjects, into appropriate workers for a specific field. I therefore set out to explore how students are formed as professionals, through processes of becoming, in private education for the beauty industry, with a special interest in how gender is at play through this process. ${ }^{5}$

\section{The beauty industry and its educational sphere}

\section{The beauty industry}

The beauty industry in Western societies is one of the most gender-specific vocational fields, where women dominate as workers. The industry is also femininized if we look at who is the target group for product development and advertising, and who mostly consumes products and services (Jones, 2010). Beauty work is also to a great extent guided by dominating ideals of femininity (Gimlin, 1996; Scranton, 2001), even though beauty products have more often been connected to a commercialization of masculinity (Edwards, T., 1997; Nordberg, 2005). However, as Black and Sharma (2001, p. 101) point out, “men

\footnotetext{
${ }^{3}$ This percentage has decreased from $37 \%$ in $2008^{3}$ due to changes in the curriculum, originating from the educational reform of 2011 (GY11). These changes made it harder to enter higher education for students choosing vocational programmes.

${ }^{4}$ Financial aid for studies refers to the various grants and loans for which students may be eligible when attending a university, adult secondary education programme (Komvux), national adult education programme, folk high school or upper secondary school. Student aid includes both grants and loans. At present, student aid is approximately 9000 SEK, of which approximately $30 \%$ is a grant.

${ }^{5}$ When it comes to beauty education in Sweden, private alternatives for adults are by far the dominant form of education.
} 
are not required to paint, moisturise, deodorise, and dehair their bodies in order to appear masculine”. Such activities are nevertheless part of the everyday routines of femininity (Holland, Ramazanoğlu, Sharpe \& Thomson, 1994). Working in a beauty salon is often perceived as low-status work, and professional status has long been a sensitive issue for the industry (Black, 2004; Toerien \& Kitzinger, 2007). The beauty industry in general has been undervalued, ridiculed and distrusted by the public, and at the same time has been a subject of feminist critique. ${ }^{6}$ These issues of legitimacy cannot be separated from the gendered nature of the industry (see e.g. Black, 2004). Namely, associations with beauty make it difficult to claim knowledge and skills associated with intelligence simultaneously, and dualities that separate beauty/brains and body/mind are further correlated with femininity and masculinity (Black, 2004). Workers in the beauty industry are thereby produced through femininity in derogatory ways. This could affect how workers in this sphere view themselves, construct their knowledge and skills, and operate as professionals.

At the same time, the beauty industry is expanding rapidly. Internationally, the industry went from having a turnover of 104 billion SEK in 1989 to a turnover of 333 billion SEK in 2008 (Jones, 2010). In Sweden, sales of "decorative cosmetics" and skin care increased from 6.7 billion SEK in 2011 to 9.3 billion SEK in 2015, which is an increase of 39 \% (the Swedish Union of Chemical Technical Suppliers, 2017). In the skin and spa therapy field in Sweden, the total turnover increased by $95 \%$ between 2008 and 2015, the number of salons increased by $15 \%$ and the number of employees by $60 \%$ (the Swedish National Organisation for Skin Therapists, 2015). This growth is also reflected in the educational sphere, where new providers are starting up.

The beauty industry is still unregulated in Sweden and anyone is allowed to perform beauty treatments, start and run a salon, a spa, etc., or provide education. The National Board of Health and Welfare reported on the beauty business in 2013, presenting a proposal for increased regulation of "cosmetic treatments". They suggested that cosmetic surgery and injections with Botox and fillers should be equated with health and medical care and should be regulated legally in the Health and Medical Services Act (the National Board of Health and Welfare, 2013). In 2015, investigators appointed by the government drew up a proposal to strengthen the protection of individuals when it comes to cosmetic treatments and surgery. However, they suggested that these treatments should be regarded as consumer services, not as health and medical services, and should not be legally regulated in the Health and Medical Services Act, but in consumer legislation. It was also suggested that procedures that require medical knowledge and experience, and that can entail considerable health risks, should be performed by medical professionals (SOU 2015: 100). The proposals included in this investigation have been heavily criticized by several of the referral bodies,

\footnotetext{
6 The feminist critique has mainly been aimed at calling attention to how normalizing and promoting an obsession with looks and beauty have devastating consequences for the lives of women (Bordo, 1990; Wolf, 1991).
} 
and are not regarded as sufficient to form the basis for legislation. Therefore, the National Board of Health and Welfare has been appointed to investigate these issues further, and will present the results of this commission on September 30, 2018, at the latest (Government Offices of Sweden, 2017).

\title{
Beauty education
}

In beauty education, there are multiple vocational titles, educational specializations and compositions, which make up a field that is neither clear nor easily described. Statistics Sweden's ${ }^{7}$ definition "beauty treatments" serves as a guideline, including spa treatments, skin therapy and other practices performed in beauty salons, including manicures, pedicures, makeup and hair styling. To further define this field of work I here include a general description, which has been formulated by the Finnish National Agency for Education:

\begin{abstract}
Professionals within the beauty business are experts in skin care and counselling in connection with the skin, massage and makeup. In their work, they shall, for the client, be able to plan, perform and market the treatments and products available regarding the face, body, hands and feet. Moreover, they shall guide the client in the usage of colour, to find an individual style, to maintain the condition of the skin and body, to choose skin care products and provide advice about usage. Many treatments are performed by hand, but also with the help of appliances and other equipment that are constantly renewed in line with technological developments. Selling skin care and makeup products are also part of the job description. (Finnish National Agency for Education, 2000, p. 12) ${ }^{8}$
\end{abstract}

The field for this dissertation can be summarized as educational arrangements that focus on knowledge and skills for working in the field of beauty as described above. Except for the educational programmes that exist within the frameworks of handicraft education at upper secondary level (stylist, skin therapist, nail specialist, manicurist and nail therapist), private education for adults is the dominant form of education within the beauty business, and these educational arrangements are my field of research.

Even though the beauty field is unregulated, words such as "authorized" and "certified" are frequently used amongst the vocational titles in this educational sphere. The trade organizations ${ }^{9}$ have almost always been involved in the formulation of these titles, where they set their own criteria. ${ }^{10}$ The trade organizations have a great influence on the educational providers and can thereby ensure that they meet the demands and wishes of the industry. Often, trade organizations are connected to educational providers in the sense that school staff

\footnotetext{
${ }^{7}$ Statistics Sweden is an administrative agency that provides statistics for decision-making, debate and research (see Statistics Sweden, 2018).

${ }^{8}$ Translated by the author from Swedish (Finland Swedish).

${ }^{9}$ There are national Nordic and international trade organizations that specialize in different areas, such as skin, nails and hair.

${ }^{10}$ For skin and spa therapies, the biggest trade organisation is the Swedish National Organisation for Skin Therapists (SHR, shr.se), which operates at national level and is linked to CIDESCO (cidesco.com), which operates at an international level. Some schools are also linked to the international trade organization, ITEC (itecworld.co.uk), and others to the Scandinavian organization SFKM (sfkm.org).
} 
are engaged in different ways. The educational providers also cooperate with other types of stakeholders such as spa facilities, product brands, beauty salons and agencies for workers in the field, and it is not uncommon that the owners of a school also run one or more of these other types of businesses. Here, it should also be noted that a school is a profit-making business in itself - one of the school's sources of income comes from product sales in the school salon, for example. The industry - its economic sector - thereby has a great influence over the educational arrangements and how the students are to be formed for their future job roles, which underlines the relevance of exploring processes of becoming in the learning processes taking place here.

There are about 36 larger educational providers in Sweden today. The schools offer self-contained educational programmes for becoming a 'skin therapist,' 'beauty therapist,' 'makeup artist' or 'nail therapist'. In addition, the schools also offer shorter stand-alone courses in, for example, 'make up special effects,' 'hair extensions,' 'lashes and eyebrows,' 'waxing' and 'massage.' Additionally, around fifty smaller educational providers have been found online. These often consist of salons that, apart from offering treatments and selling products, also provide shorter courses. It is difficult to get a full picture of these smaller stakeholders, but the number is probably more than fifty. This number is also constantly changing and has slightly increased during the process of writing this dissertation. Beyond these educational providers, there are also Swedish stakeholders offering courses located abroad, where the students can combine a shorter or longer stay in another country with studies.

The course fees vary depending on school choice, specialization and study length. See the table below for examples:

\begin{tabular}{|l|l|l|}
\hline Programme/course & Study length & $\begin{array}{l}\text { Price } \\
\text { (SEK) }\end{array}$ \\
\hline Makeup artist & 10 weeks & 72500 \\
\hline Nail therapist & 9 weeks & 55000 \\
\hline Makeup artist & 8 weeks & 35000 \\
\hline Hair stylist & 8 weeks & 19600 \\
\hline Lash stylist & 8 weeks & 9800 \\
\hline Manicure & 1 week & 10500 \\
\hline Hair extension & 2 days & 4500 \\
\hline
\end{tabular}

Combined programmes for skin and spa therapy, where most of the field studies were conducted, cost between 85000 and 95000 SEK for about one year of training. ${ }^{11}$

\begin{tabular}{|l|l|l|}
\hline Programme & Study length & Price \\
\hline Skin and spa therapist & 60 weeks & 95000 \\
\hline Skin and spa therapist & 1 year & 90000 \\
\hline Skin and spa therapist & 50 weeks & 85000 \\
\hline
\end{tabular}

\footnotetext{
${ }^{11}$ There are seven schools in Sweden that offer a total of 12 combined training programmes in skin and spa therapy.
} 


\begin{tabular}{|l|l|l|}
\hline Skin and spa therapist & 2 semesters & 85000 \\
\hline Skin and spa therapist & 44 weeks & 85000 \\
\hline Skin and spa therapist & 2 semesters & 76000 \\
\hline Skin and spa therapist & 1 year & 41595 \\
\hline
\end{tabular}

There are also educational programmes that focus specifically on skin therapy or spa therapy, combined programmes in spa and massage therapy, and programmes with vocational titles such as "massage and beauty therapist".

All combined educational programmes include elements of business administration and/or entrepreneurship, and most schools provide practical training in a school salon. Here, the school salon provides treatments that are performed by students at a lower rate than other salons, and products are also available at market price. Practical training in the future labour market, for example in a "real" salon, is not common when it comes to the larger educational providers.

When it comes to longer, combined educational programmes, the most common ones train students to become skin and spa therapists or makeup artists, with job titles such as "beauty therapist". Regarding skin and spa therapy, which is my focus in articles II, III and IV, all practices included in Statistics Sweden's definition of "beauty treatments" are found here. Scheduled subjects are: anatomy, physiology, dermatology, chemistry, economics, hair removal, facial care, body care, makeup, manicure, pedicure, advanced skin care and spa treatments.

The newly graduated skin and spa therapist then enters a labour market that consists of spa facilities, cruise ships, salons and makeup companies. It is important to point that sales are a central task and it is also not uncommon for a skin and spa therapist to work in skin care and make up stores or in the beauty sections of department stores. Most jobs in this field are low paid, there is a lot of part-time employment, and there are also commission-based salaries. Many working in this vocational field also have another part-time job on the side to handle their economic situation.

The educational programmes to become a makeup artist more specifically focuses on makeup and styling. Sales techniques and client relations are important here as well, but it seems that the task of selling oneself as a professional, putting together a portfolio, networking, engaging actively in social media etc. is much more central in order to succeed here.

Making sales is an important task in all fields of the beauty industry, and the practices and activities that these entail require a well-groomed and respectable appearance. Namely, professionals are expected to consume the products and treatments that they sell and promote, which constructs professional bodies. The student is also constructed, not only as a consumer of education, but also as a consumer of the beauty industry in itself. These circumstances place beauty workers in a distinct position in consumer society, which cannot be separated from constructions of femininity. 


\section{PREVIOUS RESEARCH}

Educational scholars have shown how learning is a process of becoming, how vocational learning and vocational cultures transform those who enter them, and how gender is at play throughout these processes (see e.g. Colley, James, Diment \& Tedder, 2003; Somerville, 2006). VET is swarming with social processes and these processes might reinforce links between class, gender and occupational choice, and destinations, as well as the control of labour within occupational fields (Bates, 1991). Yet, issues concerning gender and power are relatively rare in VET research, calling for further exploration of this area (Niemeyer \& Colley, 2015). In the following, I will first outline the research field of gender and VET to give a more general background to this field of research. Then I will go into more specific aspects of gender and VET research that are especially relevant for my dissertation, namely VET research about emotional labour, and how gendered, preferably femininized, knowledge has been constructed in relation to vocational learning and emotional labour, constructed through VET arrangements.

\section{Gender in VET}

Extensive gender inequalities and gender segregation have been, and still are, a reality in VET in general, and there are tendencies such as gender stereotyping of vocational fields, sexist practices and discrimination, and unequal salaries (Bettio \& Veraschchagina 2009; Closing the Gender Gap, 2012; Grimshaw \& Rubery, 2007). Women perform a large part of the care and service work, and women are expected to manage their feelings better and more often than men (Hochschild, 2003). Additionally, women have more part-time contracts and are greatly underrepresented in career and leadership positions (Closing the Gender Gap, 2012).

Gender research started directing attention to VET in the late 1980s (Niemeyer \& Colley, 2015), and through this research gender inequalities were reconstructed and viewed as social practices that are "constantly reproduced through institutional arrangements as much as individual actions" (Niemeyer \& Colley, 2015, referring to Wetterer, 1995, Heikkinen, 2001, \& Mayer, 2001). VET has even been identified as contributing to these patterns (Fraser 1999). Deeper insights pointed to how VET as a social practice has "developed within culturally shaped systems of labour division” (Niemeyer \& Colley, 2015, p. 2 referring to Heikkinen, 2001 \& Mayer, 2001). Namely, persistent gender inequalities can to a great extent be related to the general division between paid labour and unpaid housework, the so-called 'male breadwinner model'. This model connects to the continual reproduction of gendered patterns in societies and is a central issue for gender equality in society in general, which includes gender segregation in the labour market and in the educational sphere of VET. 


\section{Gender segregation}

As pointed out, gendered processes of (self-)selection are argued to be particularly strong when it comes to VET (Kupfer, 2014; Niemeyer \& Colley, 2015). A field of research highly relevant to research on gender and VET is therefore research directed towards gender equality/inequality and gender segregation in the labour market - an occurrence that is one of the major causes behind unequal pay between men and women (Blau, Ferber \& Winkler, 2006). Gender segregation informs the processes in which masculinity and femininity are constructed and connected to specific occupations. Somerville (2006) argues that, especially in highly gender-segregated industries, gendered constructions are intimately implicated in questions of vocational training, learning and work. In studies on coal miners and elderly care workers, she found that the workers had "extreme versions of masculine and feminine gendered subjectivities that resulted in failure to learn and practice safety at work" (Somerville, 2005, 2006; Somerville \& Abrahamsson, 2003). Gender segregation in the labour market can be identified on several levels, and can be described as primary, external and internal (SOU 2004:43), and these types of gender segregation have various functions and effects. The primary type of gender segregation is the continual division of paid labour and unpaid housework in societies. Scholars have acknowledged the importance of taking the reproductive work into account in research on the interrelation between education and work, since reproductive and productive work are closely entangled in capitalist societies (Kupfer, 2014). Researchers have for example argued that an equal division of reproductive work, the unpaid housework that is, would mean greater equality in the labour market (Ferber \& Nelson, 2003). Furthermore, external segregation can be found between industries, branches, education, vocational fields, sectors of work and organizations, and internal segregation within organizations, companies and vocational fields (SOU 2004:43). Internal gender segregation can, for example, be the case even in a so-called gender integrated organization - an organization that has an even numerical gender representation. Namely, a scenario where women and men are mixed in the different levels within the organization and are equal in their work descriptions, salaries etc. is extremely rare (SOU 2004:43).

Gender segregation is often also divided into vertical and horizontal gender segregation. Vertical gender segregation is a way of naming the hierarchical gendered order where men and women generally hold different positions when it comes to status and prestige, with a male dominance in the higher positions. Horizontal gender segregation on the other hand refers to the unequal distribution of men and women across educational and occupational fields, where male and female students are unequally spread across subjects, courses, tracks, study programmes and/or schools, and accordingly across industries and sectors of work. Vertical and horizontal gender segregation are however interrelated, where for example femininized fields hold fewer opportunities in terms of economic gains and career enhancement compared to masculinized fields (Imdorf, Reisel \& Hegna, 2015). As described above, the beauty industry labour market is, in Western societies, dominated by women and a perfect example of horizontal segregation. The industry also features vertical 
segregation due to low salaries, the high prevalence of part-time contracts and the relatively poor career opportunities that this industry offers the (women) workers carrying out the practical beauty work. Another distinct example of horizontal segregation is the care sector, for example elderly care and early childcare, which has also been characterized by a lack of educational opportunities, even if efforts have been made to bring about change.

\section{Gendered processes of becoming in VET}

Recent developments in Swedish VET systems have highlighted questions about if and how arrangements in VET may be contributing to gender segregation. As described, VET in Sweden is mainly found in the upper secondary school system - a system that has been the subject of debate due to the severe changes it has undergone in the last few decades. These changes have entailed processes of decentralization, deregulation and marketization (Lundahl, Erixon Arreman, Holm \& Lundström, 2013) and have particularly affected the upper secondary school system. In connection with GY11 (an upper secondary school reform, implemented in 2011) researchers have identified clear lines of division between those who are fostered to become employable resources for the labour market and those whom are destined for higher education (Carlbaum, 2011, 2012; Nylund, 2013). Here, structures of class, ethnicity and gender emerge. Carlbaum (2011) shows, in her analysis of the official report that led to GY11 (SOU 2008:27), how wishes and expectations are expressed about how students in the vocational programmes should choose their programme according to traditional gender norms. It is argued in this report that such behaviour would enhance the students' chances to become employable in a labour market strongly segregated by gender within an appropriate timeframe (Carlbaum, 2011, p. 100). These gendered processes are also classed. At the same time, gender is not discussed at all in relation to the students in the programmes that prepare them for higher education (Carlbaum, 2011, p. 105). Moreover, girls' employability is problematized to a greater extent than boys' employability. According to Carlbaum, (working class) girls in the vocational programmes (not the girls in the preparatory programmes) are portrayed in the report as a burden or problem for society since they often go on to higher studies. This is constructed as a problem because the (working class) girls are not meant to be in higher education, and the prolonging of their study period means that they are non-productive for a longer period of time, which in turn means a greater cost for society (Carlbaum, 2011, p. 100). Carlbaum also points out that there are norms reproduced here about the ideal worker as heteronormatively male. Through the separation of (working) women and (working) men to be educated for work in different, separate sectors, knowledges and skills are reproduced as feminine on the one hand and masculine on the other, in line with the already strongly gendered labour market in Sweden. This is a distinct example of how gender inequalities, which also entail classed processes, and gender segregation can be informed by arrangements in connection with VET, and how the employable student subject is gendered and classed. 
Internationally, gendered processes of becoming in VET have been identified and problematized to some extent. Some of the scholars involved in the exploration of social categories and power in VET have been inspired by Bourdieu's theories. The concept of "habitus" has been adapted in the exploration of how an individual's combination of personal dispositions and structural predispositions shaped by class, race and gender is at play in relation to the various fields that VET settings constitute (see e.g. Lehmann \& Taylor, 2015; Christodoulou, 2016). Some have explored the significance of "vocational habitus" in VET - a concept that was adapted from Bourdieu by Colley et al. (2003) and since used by other researchers, in relation to gender specifically (see Beck, Fuller \& Unwin, 2006; Steno \& Friche, 2015; Taylor, Hamm \& Raykov, 2015). Colley et al. (2003) develop the concept of "vocational habitus" in their study of three vocational courses, all with gender-specific, working-class orientations: Childcare, Healthcare, and Electronic and Telecommunications Engineering. In their study of all three courses, the authors acknowledge how a process of orientation against what makes "the right person for the job" is an important part of the students' learning and adaption of the vocational culture. This orientation to a specific identity is termed as "vocational habitus" and entails a process where the students' individual agency and their predispositions related to gender, family background etc. are intertwined. This process may reproduce social inequalities when a person's predispositions are reinforced and developed in line with what is demanded by the job role and work culture. This involves not only one's behaviour, but also for example also one's feelings, attitudes and beliefs, and capacity for emotional labour (Colley et al., 2003) processes that are gendered.

As acknowledged, research on gender and VET is relatively rare, which is also the case regarding VET research about distinctly femininized vocational settings, with practical nursing as an exception (see e.g. Fejes \& Nicoll, 2010; Gordon, Benner \& Noddings, 1996; Nay \& Garratt, 2002; Skeggs, 1997; Somerville, 2006; Westerberg \& Hjelte, 2013). Research on caring knowledge will, amongst other types of gendered knowledge in VET, be elaborated on in the following.

\section{Gendered knowledge in VET}

Gendered processes in VET can in part be described in terms of how various types of vocational knowledge are gendered, which sets boundaries and decides the possibilities for the shaping of professional status for vocations. Namely, there are gender relations of power at play when it comes to professional status and legitimacy, and thereby when it comes to constructing vocational categories in general, which connects to wider discourses of masculinity and femininity. When it comes to professional legitimacy and status in VET, scientifically based knowledge holds a central position, and a masculine discourse of science is here ultimately being mobilized. Scholars have identified a cultural reproduction of masculinity when it comes to scientifically based knowledge, and have found the culture of science to be inevitably masculine (Connell, 2005; Kourany, 2002; 
Löwy, 1999; Maynard, 1997; Rose, 1994; Waerness, 1996). The most represented social category within natural sciences and technology is the white middle-class male (Lederman \& Bartsch, 2001). Scholars have also acknowledged how dominating discourses mobilized here derive from the social position that is held by men in a male-dominated society. This includes how science is produced through universality and objectivity, the specific structures of power and communication, the interpretations of scientific results and the reproduction of this culture (Connell, 2005; Löwy; 1999; Maynard, 1997; Rose, 1994). It can therefore be argued that gender relations, produced as historical effects of power, are enacted in the formation of vocational knowledge and professional status. In the following, I will outline femininized areas of gendered knowledge that become relevant in this dissertation, namely emotional labour and caring knowledge.

\section{Emotional labour}

Scholars have acknowledged how the boundaries between leisure and work have become less distinct in recent years (Lewis, 2003). For example, people now, to a greater extent than before, make certain lifestyle choices in order to become an appropriate and successful worker for a specific occupation (Waring, 2008). In connection with this process, the concept of "workstyle" (in opposition to "lifestyle") has been introduced. Where lifestyle refers to individual choices in leisure activities, workstyle instead symbolizes how the influence of work on identities has intensified to such an extent that individuals now make specific lifestyle choices in order to develop an appropriate and successful workstyle (Du Gay, 1995; Waring, 2008).

In the service sector especially, these choices extend to the emotional life of the worker. Hochschild (2003) coined the term "emotional labour" in her study of American flight attendants, a term that refers to the process of managing feelings and expressions in order to fulfil emotional requirements as part of the job role (Grandey, 2000; Hochschild, 2003). More specifically, Hochschild defines it as: "the management of feeling to create a publically observable facial and bodily display", which "requires one to induce or suppress feeling to sustain the outward countenance that produces the proper state of mind in others" (Hochschild, 2003, p. 7). Through her empirical study of flight attendants, Hochschild (2003) shows how workers' feelings and expressions of emotion happiness being the most distinct and central in the specific context - have become products that belong more to the organization than to the self. In providing a service, the state of mind or the emotional style through which the service is being provided becomes the product.

In a capitalist society, this product is then exploited and exposed to control by those who possess the means of production, seeking to profit from it. There are aspects of emotional labour in all occupations, but in their work roles women are expected to manage their feelings better and more often than men (Hochschild, 2003, p. 164). There are gendered (and classed) expectations where women are constructed through the role of nurturing others, and in a labour 
market where women hold less economic, cultural and social capital than men, they also have to rely more on their emotional resources (Hochschild, 2003).

In femininized occupational fields, like the care and service sectors, the activity of managing feelings to fit the work role is constructed through a caring discourse. This further reinforces femininity, since the responsibility for caring is still constructed as something ascribed to women (Meyer, 2000; Waerness, 1996). The care and emotion work that women perform is often unacknowledged and undervalued, since it is often reduced as skills that are natural for women skills that women automatically gain in their experience of being female (Nay \& Garratt, 2002). Research on emotional labour is therefore particularly important to deepen knowledge about how gendered processes is at play in the learning of emotion work in strongly femininized settings. Moreover, it is important to acknowledge aspects of emotional labour in vocational learning since it is often tacit, and unacknowledged as pointed out, but at the same time crucial for the vocational learning process and for operating successfully in many occupations. Most research on emotional labour has however been conducted in relation to worklife, where it has been problematized in a range of vocational settings (Pierce, 1995; Stenross \& Kleinman, 1989), mostly located in the service industry (Brotheridge \& Grandey, 2002; Seymour, 2000; Totterdell \& Holman, 2003) but also in the health services (Allan \& Smith, 2005; Smith, 1992; Theodosius, 2008). Emotional labour has been acknowledged in VET research to some extent, especially when it comes to VET for nursing (see e.g. Msiska, Smith \& Fawcett, 2014) but further explorations are needed here. Gendered aspects of emotional labour in VET in particular have received little attention, with an exception in Colley (2006), who explores class, gender and emotion in childcare education and training. Drawing on feminist Marxist theory, the writings of Bourdieu, and inspired by Hochschild, she explores how classed and gendered locations combine with VET in the construction of norms about the correct and appropriate emotions in childcare. Understandings of feelings and emotion work as an individual are critically discussed and a social understanding is put forward. Furthermore, Colley argues that emotional labour should not be seen as a sub-category of caring, but as a form of paid labour - a capacity to labour - which, drawing on a Marxist framework, can be increasingly exploited by those who hold the means of production. Namely, Colley argues, the problem is not that the emotion work carries a cost for the worker because children in this case consume one's emotional resources - this benefit is its private use-value but "the appropriation of emotional labour put to work for exchange-value - for profit - that turns it into a commodity, and a potential source of alienation" (Colley, 2006, p. 27).

Even though emotional labour is a concept developed within a Marxist framework, with epistemological points of departure that differ from a poststructuralist view, it is relevant for this dissertation since this research on learning to labour with feeling is an example of how gender and class intertwine in vocational learning and in the development of vocational knowledge as gendered knowledge. However, my focus in this dissertation is rather to explore how feelings and emotion work discursively emerge as a resource in the 
production of professional subjectivities. In the following, research on gender and care work, and the knowledge it requires, will be outlined.

\section{Caring knowledge}

Care is a wide and complex concept that is produced in varying ways throughout different discourses, as a specific historical and cultural concept (Mariskind, 2014; Warin \& Gannerud, 2014). The care work performed in different settings therefore has partly different values and meanings. However, according to Noddings (1984, 2005), it can be seen in all settings as "a way of being in relation" rather than a set of behaviours. Acknowledging caring knowledge in VET research can be viewed as a feminist action in itself; many feminist scholars have underlined the importance of highlighting the care work that is often ascribed to women, and the knowledge that this work requires. Instead of being regarded as important knowledge, caring dispositions have been romanticized and sentimentalized, and viewed as something "natural" for women (Gordon, 1996; Nay \& Garratt, 2002). Scholars have also shown how occupational choices for care work and learning to care in VET intertwine with classed and gendered processes (see e.g. Colley et al., 2003; Fejes \& Haake, 2013; Fejes \& Nicoll, 2010; Skeggs, 1997; Somerville, 2006).

Skeggs's (1997) ethnographic study of (working class) women in caring courses in the UK is an influential piece of feminist theory and cultural theory, and offers important insight into the gendered (and classed) processes in becoming a caring subject. Skeggs argues that the women in her study's classed and gendered positions partly excluded them from the labour market and the education system, and that they were delegitimated through the associations of non-respectability. The struggle to become "respectable" - a concept central to Skeggs's work - entailed processes of policing oneself through opening up every aspect of one's life, such as one's caring practices. Caring and feminine performances were created to some extent out of necessity - performances that it is impossible to avoid if one wants to appear feminine and respectable. For example, the women's feminine appearance was “complemented and reinforced by their caring behaviour” (Skeggs, 1997, p. 165). Being a caring subject entails not only having the right skills - one also has to be a particular sort of person, a person with attributes that connect to wider discourses of femininity and motherhood. Skeggs (1997) acknowledges how the positions that caring subjects are offered entail job roles where practices and personal dispositions become inseparable; "the caring subject is constructed by the conflation of caring for with caring about, in which practices of caring become inseparable from personal dispositions" (p. 56). Caring for refers to the practical tasks of caring such as cleaning and cooking, not necessarily relating to caring about, which refers to caring dispositions on a personal level, assuming a relationship to the subject being cared for. One cannot perform caring practices without being caring, and one cannot be caring without incorporating the social dispositions the care work requires, positioning oneself as feminine in specific ways. Moreover, it is not enough to develop and incorporate the right dispositions in order to acquire respectability, moral status and value; one must put these dispositions on display 
through performance. "Institutional legitimation" was here a powerful reinforcement for the performance of this caring subject, highlighting the role of institutional arrangements in VET.

Skeggs (1997) also describes the shaping of "the caring self" in her material, where it is constructed through concrete caring practices and through the women's investments in these practices (p. 57). Skeggs argues that this caring self, as it is lived and produced in the courses, is a gendered (and classed and raced) self. As it is generated in daily practice, the caring self is practical, not academic, and it is mainly in the evaluation of the practical that the women become involved in monitoring and judging others and themselves. So, the caring, gendered, self is "embodied in the institutional and technical practices of the caring courses" (p. 72), becoming both a performance and a technique for valuing responsibility and respectability. An example of such a technique is how the women are taught to enjoy the fulfilment of doing care work to such an extent that they can be left doing it without any direct control. This fulfilment is produced as a pleasure of giving, which through a poststructuralist perspective can be seen as a productive power that governs the worker in valuing emotional gains more highly than economic gains.

In connection with Skeggs's (1997) study, and inspired by Foucault (see e.g. 1988b), Fejes and Nicoll (2010) have explored the relations of care through elderly care workers' descriptions of themselves and their work, and argue that this technology of the self can be viewed as a calling to care. Recognizing how care work is constructed as women's work, they here draw on the notion of a calling, which connects to past religious and secular discourses of a calling to God and nursing, and explores the ruptures and irregularities of emphasis in the past to consider present descriptions of caring relations. In the workers' descriptions, a specific calling to care is mobilized, shaping context-specific, caring subjects.

Somerville (2006) also explored care work in elderly care, drawing on a poststructuralist perspective, but focused more on the educational sphere of elderly care. She acknowledges how the gendered, femininized, construction of care work operates in processes of becoming, in constructions of femininized caring subjectivities. Like Skeggs, institutional arrangements and practices are highlighted as informing these processes. Somerville underlines the importance of considering what goes on in the interrelation between preparatory training and workplace learning, where the knowledges and practices from these two parts of the curriculum often came into conflict. The vocational training entailed complex negotiations around identity and learning and around knowledge and care work, which highlights the gendered processes around the construction of caring subjectivities. Issues were also raised that acknowledge the reproduction of privilege and disadvantage connecting to gender - the workers were for example powerless to influence the work practice. 


\section{Concluding remarks}

Scholars have drawn attention to the need for further explorations on gender and VET (Niemeyer \& Colley, 2015) and by reviewing the literature it becomes clear that this field of research has not been sufficiently explored. This is somewhat surprising since the VET research that has acknowledged gendered processes has shown strong implications for the importance of such research. Gender inequalities and gender segregation in the labour market have received substantial attention from scholars outside the VET field, but VET research about if and how vocational arrangements are a part of these processes, and also might reinforce them, seems to need more attention.

I also draw the conclusion that the knowledge gap on gender and VET extends to understandings of the gendered body in learning processes. Research on bodies in the social sciences and humanities has grown since the 1980s - in parallel with the development of the research on gender and VET, but has not been picked up by VET scholars. Processes of becoming are closely connected to bodily representations, and the body is also central to feminist theoretizations on gender. Incorporating such understandings of the body into gender and VET research would probably visibilize more or less tacit knowledges in different specializations, and provide deeper understandings of how gender relations of power are at play here.

Gender and VET has been explored, discussed and problematized from a spread of theoretical perspectives, but poststructuralist approaches are, with a few exceptions (Fejes \& Haake, 2013; Fejes \& Nicoll, 2010; Skeggs, 1997'2) still rare. In gender and VET research inspired by Foucault, a view on power as productive has for example provided new understandings of how vocational subjects are formed and governed to become caring subjects. Further explorations of how discourses operate in vocational processes of becoming (see Fejes \& Haake, 2013) can also provide deeper insights into how gender informs these processes in VET.

Research that problematizes a clearly defined dichotomy of male and female (see e.g. Butler, 1990, 1993) are also needed in order to meet rapid changes in society where gender and gender inequalities might be produced in new and alternative ways (see e.g. Niemeyer \& Colley, 2015). In this dissertation, I draw on poststructural feminist theory (Butler, 1990, 1993, 1997; McLaren, 2002; McNay 1992; Ramazanoğlu 1993), which allows me to explore how both masculinities and femininities may be produced in the more or less gender-specific settings of VET, which may provide knowledge about how gender relations of power are at play in these vocational learning processes. I strive to contribute to research on gender and VET through the focus on a vocational setting that is distinctly femininized. Even so, in the understanding of the processes and knowledges at play here, it is important to acknowledge how they connect to wider discourses of masculinity. I will also acknowledge how

\footnotetext{
12 Skeggs's study is mainly based on a theoretical framework represented by Bourdieu, but also includes reasoning inspired by Foucault.
} 
bodies are produced in processes of becoming, taking into account how these processes are gendered. My theoretical framework will be described further in the next chapter, which ends with a clarification of the aim and research questions. 


\section{THEORIZATION}

In order to analyse the production of subjectivities in conjunction with and in relation to vocational learning - taking gender and power into account - this study is inspired by the writings of Foucault (1979, 1980, 1982, 1983, 1988a, 1988b, 1990, 1993, 1995, 2007) and poststructural feminist theory (Butler, 1990, 1993, 1997; McLaren, 2002; McNay 1992; Ramazanoğlu, 1993).

A poststructural perspective provides analytical tools that visibilize the workings of power, how relations emerge and how such relations govern the production of subjectivities. Such theorization can therefore give an insight into the formation of student subjectivity in beauty education and how gender is at play throughout these processes. Inspired by Foucauldian resources, I have analysed how vocational subjectivities emerge through the ways these are positioned and self-position through discourse. Since these processes of subjectification are operationalized in a femininized setting, where students are prepared for a labour market strongly segregated by gender and a feminine job role, one main focus is specific processes around constructions of femininity. In order to understand how gender is at play throughout these processes, I turn to poststructural feminist theory inspired by Butler $(1990,1993,1997)$ and the writings of feminists whose work discusses the implications of the crossover between feminist thought and the resources of Foucault (McLaren, 2002; McNay, 1992; Ramazanoğlu, 1993).

Such theorization is intertwined with the method. Here, the poststructuralist concepts of power, discourse and subjectivity, which I will present in the following, constitute the toolbox for performing the analysis. These concepts provide me with guidance and a way of answering my research questions. In exploring the production of subjectivities - the main focus of this dissertation - processes are identified where power operates and discourses are being mobilized. Thus, these concepts are intertwined and, together with a poststructural feminist perspective on gender and gender relations of power (and on the production of bodies), they constitute the theoretical framework for this dissertation. In Foucault's quest to dissolve and scrutinize the taken-for-granted, he did not want to create a once and for all constructed system of ideas to which he would have to adapt. He rather defined the concepts in various ways throughout his career, making it impossible to summarize their meaning. Instead, I will describe the concepts that have served as guidance in this dissertation specifically.

A poststructural conception of power is central in the theorization of this dissertation, and differs greatly from how power is usually understood. Instead of viewing power as something an individual or group can possess and exercise upon others, power is here rather understood as productive, operating relationally, and can be perceived as a positive force that reinforces itself and the object/subject it works upon (Foucault, 1980, 1993). I will start by outlining this 
concept, since it serves well as a starting point for then describing the concepts of discourse and, eventually, how I view the processes through which subjectivities are produced. However, I continuously return to the three concepts throughout the text, in order to map out how they relate to each other. I will also continuously return to the poststructural feminist theory that has inspired my theorization and provided me with ways of understanding gendered processes in my analysis.

\section{A productive concept of power}

The common notion about power is that it can be possessed by people and institutions, and be exercised by the powerful against the powerless, mainly being concerned with oppressing and constraining (Mills, 2003) in given and inescapable structures that distribute power amongst different groups of people (Lenz Taguchi, 2014). Foucault's writing is critical to such a notion of power, and instead he has shown how power can be understood in terms of a constantly ongoing production, in which we all are involved, being ubiquitous, operating within everyday relations. This power can be viewed as a verb, as doing something, rather than a noun, a possession, something that is, that can be held on to (see e.g. Mills, 2003). When we think, act, speak and move - taking things for granted - power operates through us. We hereby become discursively constituted subjects through power (see e.g. Lenz Taguchi, 2014). Power is for example being materialized when it comes to the beauty industry and the obsession with female appearance in our cultures, in consumers' wishes and desires, and in bodies. This also includes pampering treatments (a relaxing massage for example), where power works upon bodies directed through discourses. This conception of power centres on the question of how power operates, and allows to make visible how particular processes of becoming productions of subjectivity that is - in beauty education are made possible. Viewing power as productive, as something that circulates (Foucault, 1980), also allow us to examine even the most constraining measures, since resistance is built into Foucault's conception of power in that all power produces resistance. This resistance "takes the form of counter discourses which produce new knowledge, speak new truths, and so constitute new powers” (Ramazanoğlu, 1993, p. 23). Instead of simply being recipients of power, individuals are seen as "the 'place' where power is enacted and the place where it is resisted" (Mills, 2003, p. 35). Through such a conception of power, people become both products and producers of discourse (Foucault, 1980, 2007), and power therefore both acts on the subject and is constituted through it (Butler, 1997). Power is therefore constantly performed, arising in the moment, in a particular context, being multiple and taking different forms (Mills, 2003, citing Foucault, 1988b).

Butler's notion of performativity provides guidance in analysing doings of gender. She states that the process of doing gender is operationalized by performative acts. These acts entail behaviours of constantly imitating and repeating femininity or masculinity through controlling images (Butler 1990), producing bodies in particular ways. In the positionings and self-positionings of 
the participants in this study for example, gender is shaped as effects of power through the discursive resources that are available. Moreover, behaviours of imitating femininity in Western societies cannot be separated from the beauty industry - these behaviours entail for example the performance and use of various beauty treatments and products.

One central aspect of Foucault's writings is the view on power and knowledge as intertwined, a connection that Foucault describes as power/knowledge. This relationship is important to outline in order to understand the process through which power relations, and the production of certain subjectivities, are made possible. In his writings, Foucault was concerned with the processes through which something becomes established as a fact, as true. How is it that we know something? He writes:

\begin{abstract}
Perhaps we should abandon the belief that power makes mad and that, by the same token, the renunciation of power is one of the conditions of knowledge. We should admit rather that power produces knowledge (...) there is no power relation without the correlative constitution of a field of knowledge, nor any knowledge that does not presuppose and constitute at the same time power relations. (Foucault, 1995, p. 27)
\end{abstract}

So, the two elements "power" and "knowledge" are dependent on one another. For example, the knowledge that is constructed as the "right" knowledge about skin and spa therapy, and the beauty business in general, constructs the successful skin and spa therapist as for example feminine, caring, self-sacrificing and well groomed, and this is an operation of power through which vocational subjectivities are produced. Foucault writes:

\footnotetext{
...basically in any society, there are manifold relations of power which permeate, characterise and constitute the social body, and these relations of power cannot themselves be established, consolidated nor implemented without the production, accumulation, circulation and functioning of a discourse. There can be no possible exercise of power without a certain economy of discourses of truth, which operates through and on the basis of this association. We are subjected to the production of truth through power and we cannot exercise power except through the production of truth. (Foucault, 1980, p. 93)
}

Here, Foucault describes how power, in order to operate, has to be grounded in "discourses of truth", in knowledge about the things it operates on and in relation to. So, particular ways of speaking about a vocation, a learning process or a specific task are made possible by what discourses make available to us (Foucault, 1990). Thereby, particular locations in power-knowledge regimes provide possibilities for students in the beauty industry to be positioned and selfposition. When something is established as true, something else needs to be discredited and denied. This involves processes of exclusion where certain discourses are produced ahead of others (Mills, 2003). Mapping out how these processes come to be - what makes them possible - is crucial for a critical examination of vocational knowledge for example. That way, an intertwined conception of power/knowledge is a part of the toolbox for analysing how vocational subjectivities are produced in the material. 
Foucault's quest in identifying these multiple power relations, where one concern settled on local forms of power and how they are negotiated in the moment, have influenced feminist theorists (Mills, 2003). My use of poststructural feminist theory entails an analysis in which the assumption that gender is a starting point for relations of power is central (see e.g. Ramazanoğlu, 1993). Since power here is not viewed as something a group can possess, a gendered power order where men hold a superior position to women becomes an impossible structure of thought. This questions the ways in which (some) feminists have thought about gender oppression. Through a poststructuralist view on power, gender relations are rather viewed as arising in the moment, as historically specific effects of power. These historical effects are constituted of changeable social forces rather than of our fixed, physical being (Ramazanoğlu 1993).

In this way of thinking about power, the body then becomes a product of multiple processes of power (Foucault, 1988a). The activities and practices taking place in beauty education centralize around the body, and bodily representations are closely connected to processes of becoming, especially in this particular VET field. The notion that bodies are produced through multiple processes of power is central in this study, in the view of how gender and power operate in the texts analysed. Closely related is Foucault's writing on sexuality as a product of historically and culturally specific relations of power, as opposed to a view of sexuality as biological (Foucault, 1990). This has been taken up by feminists in reasonings about how women's experiences are formed through controlling notions about female sexuality (McNay, 1992). According to Foucault, the body is disciplined through a multiplicity of powered processes, such as the power techniques that we ourselves exercise on our bodies - through different sorts of body care for example (Foucault, 1988a). In his writings on biopower, Foucault also acknowledges a "micro-physics" of the body. Here, the aim of power is to discipline bodies in ways that are conducive to their productivity in a certain organization (Howarth, 2000), for example how professional bodies are produced in beauty education to fit the future job role. Furthermore, power comes from below, and bodies are imbued with power in expressions and gestures and in the ways in which people learn to live and work together (Foucault cited in Sheridan, 1980, p. 217). So, in Foucault's reasonings about bodies, emphasis is put on the production of bodies through power, which is grounded in discourses of truth.

The operation of power and the way subjectivities are shaped could also be seen as a governing relation. Usually, we might think about the power of politicians over legislation, limiting or making more possible certain behaviours among the population. However, as Foucault argued, government represents not only the management of states, but the way in which "the conduct of individuals or of groups might be directed” (Foucault 1982, p. 221). Here, more or less considered and calculated modes of action are destined to "act upon the possibilities of actions of other people", and to govern is therefore "to structure the possible field of actions of others" (Foucault 1982, p. 221). This governance is broadly defined as "the conduct of conduct" (Foucault 1982, 2007). 
Accordingly, through my participants' (self-)positionings, they govern themselves as well as others when they act in line with norms, e.g. about how to relate to one's own body. This process is also understood through Foucault's reasonings about technologies of power and technologies of the self (1988a).

\section{Discourse and discursive practices}

Discourse becomes central to an understanding of how power operates. In his writing, Foucault used discourse in different ways, but according to Mills (1997), one of the most productive ways of viewing discourse is as "practices that systematically form the object of which we speak" (Foucault, 1982, p. 49). This means that discourse not only is about language. Instead, discourses are practices that can be identified "because of the systematicity of the ideas, opinions, concepts, ways of thinking and behaving which are formed within a particular context, and because of the effects of those ways of thinking and behaving" (Mills, 1997, p. 17). Such a view of discourse entails that what can be understood and what can be said and done is constituted culturally, socially and historically, and therefore structures the way that we can perceive reality; there is no reality that we can apprehend or discover outside of discourse. According to Foucault, there might however be a reality outside of the text, a materiality to things, but this was not his concern when analysing discourse (Mills, 1997).

In discussions about the discursive and the non-discursive in Foucault's writings, the body is often used as an example (Börjesson, 2003). ${ }^{13}$ Bodies are namely seen as non-discursive in their materiality. At the same time, the entity called "body" (a word that in itself is a discursive production) does not exist in a non-discursive vacuum, but is "under the sovereignty of discourse" (Kendall \& Wickham, 1999, p. 39). Kendall and Wickham (1999) discuss torture as a discursive practice that works on bodies directed by discourses. Through this way of thinking, beauty and spa treatments are viewed as discursive practices that work upon bodies, producing them in particular ways. This is a production directed by for example medical discourses and discourses on femininity and beauty. So, even if the body itself is non-discursive, nothing can exist in an entirely non-discursive realm (ibid). Meanings of femininity are for example materialized through our bodies in different ways in different contexts (see e.g. Lenz Taguchi, 2014; McLaren, 2002; McNay, 1992; Ramazanoğlu, 1993).

Furthermore, there is no prediscursive, rational self that exists outside of, and separated from, discourse, but we are constituted through and within discursive regimes - some more dominant and more accessible than others. Dominant discourses of femininity, heterosexuality, fertility and motherhood have for example structured and conditioned the lives of women in different ways, such as disciplining their bodies for an appropriate appearance. This does not mean however that discourses can be divided between dominant ones and

\footnotetext{
${ }^{13}$ See for example Mills (2003, p. 55f) and Kendall and Wickham (1999, p. 39f).
} 
those that are dominated, "but as a multiplicity of discursive elements that come into play in various strategies” (Foucault, 1990, p. 100).

Such a Foucauldian notion of discourse provides guidance in my understanding of the processes through which subjectivities are produced. This means that my focus concerning discursive formations lies upon how discourses operate and how my participants engage with discourse in their everyday training and in their stories about themselves in this training, rather than simply analysing how discourses relate to each other or the internal rules of a discourse in isolation. Discourse is namely active in the production of something else (Mills, 1997) - subjectivities, for example. Thus, in line with the Foucauldian theorization about power, discourses are also viewed as productive - they have effects.

Let us connect to Foucault's notion of power/knowledge and truth. Namely, it is because of this relationship (power/knowledge) that discourse has effects; "it is in discourse that power/knowledge are joined together" (Foucault 1979, p. 100, cited in Howarth, 2000, p. 67). Knowledge of the world can only be obtained through discourse (Mills, 1997). The possible ways of thinking about an object are decided by the (never)ending discursive possibilities that open up and close for thoughts, understandings, statements and actions to become, in a constant flow (Foucault, 1990). In line with this way of thinking, the production of subjectivities is also informed by power/knowledge since we are positioned and self-position as the objects we can know something about, including ourselves as subjects. Furthermore, what counts as true in a society is discursively produced through power; truth can never be obtained since one can never speak from a position located outside of discourse (Winther Jørgensen \& Phillips, 2000). Instead, societies produce truth - it does not just appear - and competing discourses struggle to gain the authority to determine what is true (Foucault, 1993). These commonly accepted truths can therefore be scrutinized, questioned and dissolved through critical analysis. The main interest for Foucault in this regard was to analyse the processes through which something becomes considered as true and something else becomes discredited - the effects of power/knowledge (Foucault, 1990). Mills (1997) gives the example of how medical science in Western societies holds the authority of being scientific and true, and how this process includes the miscrediting of other alternative ways of viewing the body. Such processes can also be identified in my material, where students position themselves as professionals through scientific knowledge, and at the same time reject perceived conceptions about how skin and spa therapists only engage in vain practices that girls and women perform in their strivings to obtain beauty, not holding "real" knowledge, and not performing professional practices. This is an example of how dominating discourses of science inform the way that beauty students think about themselves and their practices and how they present themselves as professionals, which is a process where power/knowledge and truth act through the subject. However, we are not just passive dupes, but active subjects that come to be in processes where power is enacted and contested (Mills, 2003). Foucault (1979) writes: 
We must make allowance for the complex and unstable process whereby discourse can be both an instrument and an effect of power, but also a hindrance, a stumbling block, a point of resistance and a starting point for an opposing strategy. (Foucault, p. 101)

Here, discourses are both the means of production and the source of possibilities for resistance. This way of thinking about discourse has been picked up by feminist theorists, who have found it fruitful to view femininity in terms of discourses of femininity, in opposition to femininity as an imposed ideological category. Instead of being passive victims of oppression, women actively negotiate discursive constraints they are engaged in, keeping these discourses in place, but also "trying to dismantle elements of them and replacing them with other more productive elements" (Mills, 1997, p. 87).

How then are discourses at play in gendered processes? Discourses of femininity and masculinity affect how people present themselves in various times and places. These are broader discourses that are manifold and sometimes contradictory, with conflicting sets of statements, having different political intentions. But they do have a similar function. Namely, these discourses distinguish men and women from each other and identify them as fundamentally different. In this way, "discourses, or discursive formations, are groups of statements which deal with the same topic and which seem to produce a similar effect" (Mills, 2003, p. 64). They lead to "the reproduction of other statements which are compatible with their underlying presuppositions" (ibid.). In the following, the theoretical conditions for the production of gendered subjectivities will be further outlined.

\section{The production of subjectivities}

As argued, the shaping of subjectivities is a central focus in this dissertation. How then do subjectivities emerge?

A Foucauldian, and poststructuralist, view of the subject differs greatly from the Western way of viewing it: as autonomous, sovereign, essential and uniform (Davies, 2006; Kendall \& Wickham, 1999; Lenz Taguchi, 2014; Winther Jørgensen \& Phillips, 2000). Instead, the subject is understood as decentred and fragmented, produced in specific ways through discursive practices. This approach allows the subject to take on numerous positions through discourse, allowing an analysis where subjectivity becomes multiple subjectivities, emerging through regularities of description and self-description. Accordingly, this also allows us to talk about femininity as multiple femininities, making it possible to visibilize relations of power amongst femininities, variations between groups and within groups, and to recognize an individual's subjectivity as diversified. For example, we are allowed to examine how certain femininities are produced as respectable and others are not (see e.g. Skeggs, 1997), and how such a process is made possible. These subjectivities are "precarious, contradictory and in progress, constantly being reconstituted in discourse every time we speak" (Weedon, 1997, p. 32). Thus, Foucault's reasonings are focused upon a decentred subject, and the production of 
subjectivities is a process with no beginning and no end, driven by interactions between the self and others.

However, Foucault was mainly concerned with how certain thoughts and statements are made possible - how impersonal discursive processes operate and less concerned with how individuals carve out a space for themselves to operate within abstract discourses (Mills, 2003). Poststructural feminist theorists inspired by Foucault have developed his reasonings on subjectivity further, and have drawn attention to how socially ascribed categories like gender, sexuality, class, ethnicity and function interact and produce a plurality of locations for the production of subjectivity (Lenz Taguchi, 2014; Butler; 1990; Connell, 1996). The focus has also been directed towards the issue of agency. Here, "the problem of agency" has been widely debated, which, in short, is about whether power exists prior to the subject or is produced as its effect (see e.g. Butler, 1997; Diamond \& Quinby, 1988; Lenz Taguchi, 2014; McLaren, 2002; McNay, 1992). Butler (1997) has developed Foucault's reasoning on subjectivity in regard to agency, and subjectivity is here seen as an ongoing construction taking place through a constant process - subjectification. She writes:

\begin{abstract}
According to the formulation of subjection as both the subordination and becoming of the subject, power is, as subordination, a set of conditions that precedes the subject (...) This formulation falters, however, when we consider that there is no subject prior to this effect. Power not only acts on a subject but, in a transitive sense, enacts the subject into being. As a condition, power precedes the subject. Power loses its appearance of priority, however, when it is wielded by the subject, a situation that gives rise to the reverse perspective that power is the effect of the subject, and that power is what subjects effect. A condition does not enable or enact without becoming present. Because Power is not intact prior to the subject, the appearance of its priority disappears as power acts on the subject... (Butler, 1997, p. 13)
\end{abstract}

Here, power is constituted through the subject at the same time as it acts on it, in a simultaneous process. The agency that the subject is given through this way of thinking is however not understood as being able to act outside of discourse; instead, it opens up the possibility for changes that are not predetermined. The way the subject is constituted is namely the precondition for its agency, even if this agency depends on the power and the politics through which the subject is produced. This agency thereby becomes locked into discourses of resistance (Butler, 1997).

As described in the section on power, gender comes into existence when people perform it. Here, gender is not understood as produced by subjects with agency, but by:

... a process of reiteration by which both 'subjects' and 'acts' come to appear at all. There is no power that acts, but only a reiterated acting that is power in its persistence and instability. (Butler, 1993, p. 9)

As Butler's notion of performativity implies (1990), a gendered subject is not constituted once and for all; rather, such a subject is performed time and time again. Butler also questions the distinction of sex and gender. Biology, nature, sex and gender are all just as much discursively produced and maintained 
through social practices, illustrating how (a Foucauldian) power is productive in that sense (Butler, 1990). It is namely through the performance of gender that sex is ascribed to bodies (see e.g. McLaren, 2002). Returning to Foucault's antiessentialist stand concerning subjectivity, Ramazanoğlu and Holland (2002) writes concerning feminist subjectivity:

\footnotetext{
The knowing feminist cannot be essentially, naturally or authentically a woman, because she is historically variable and socially constituted. In this view, feminine or masculine natures are not something people are born with. They are produced through the discourses of femininity and masculinity of a given way of thinking, and the effects of these discourses. (p. 90)
}

These effects can for example be the way that we are positioned and position ourselves as professional in our occupation. Through such a view on subjectivity and agency, special attention can be directed towards how the students in beauty education engage with discourse in this micro-context of education and training how they take up and mobilize discourse in their actions and statements. Statements are a part of, and are made possible through, discourse and the students are positioned and self-position simultaneously. Thus, we are conditioned by our location in power/knowledge regimes, through which we are positioned and hold the agency to self-position and position others as well as knowledge about our surroundings. Both Foucault (referred to in Kendall \& Wickham, 1999, p. 37) and Butler (1997, p. 15) use the phrase "conditions of possibility", which are the meanings that the subject make of the discourses available. This does not mean that a particular production of subjectivity is necessary, but that it is made possible through multiple relations of power (see e.g. Kendall \& Wickham, 1999).

Subjectivities can nevertheless adopt a particular shape through the regularities of discourse - these regularities can for example form vocational subjectivities in particular ways. These processes pinpoint how the subject selfpositions in relation to itself and in relation to others - a process that distinguishes what is the "right" way to be in a particular location (Foucault, 1988a). In this way, the centre of my attention has been to identify reoccurring ways through which students are positioned and self-position, rather than analysing the negotiations taking place when individual people self-position. Even so, these negotiations are sometimes analysed and described in order to illustrate the circumstances through which these reoccurring ways of positioning are taking place, and to visibilize the students' participation and thereby their agency.

\section{Concluding remarks}

So, in order to explore the production of vocational, gendered subjectivities in education and training for the beauty industry, I mobilize a theorization where Foucault's conception of power, discourse and subjectivity, and the way poststructural feminists have taken up and discussed these conceptions, are central tools for analysis, together with a view on gender informed by 
poststructural feminist theory. How these theoretical tools have been used in the analysis will be further elaborated on in the chapter on methodological approach. 


\section{AIM AND RESEARCH QUESTIONS}

The overall aim of this dissertation is to answer the question: How are vocational, gendered subjectivities produced in vocational education for the beauty industry? More specifically, the following research questions are posed:

- How are the processes, through which subjectivities are produced, enacted in the educational settings, including the recruitment to these settings?

- How is the professional skin and spa therapist constructed and what makes these constructions possible, or even desirable?

Through posing such questions I will show how students in beauty education are shaped as professionals, where I further explore the (gendered) knowledges that are at play in these processes. I also explore efforts to attract students (how particular strategies to attract future students shape student subjectivity), how (professional) bodies are produced, as well as emotional workers in work surrounding the body. Posing these questions allows me to achieve a deeper insight into how gender relations of power are at play in the discursive processes of becoming in this sphere. 


\section{METHODOLOGICAL APPROACH}

In order to understand how students are constructed as professionals in private beauty education, and how gender is at play throughout such processes, I have been inspired by a field study tradition. Such a tradition involves the researcher participating in a specific setting, asking questions and actively noticing the speakings and doings of this setting over an extended period of time. Here, the researcher collects the data available in order to obtain a deeper understanding about the issues in focus for the research (Hammersley \& Atkinson, 1995). In line with such an approach, I have collected the material for this study in three ways: I have collected material consisting of website that are available for future students, and I have conducted interviews with twenty students and field observations at two different schools for skin and spa therapy education and training.

The process of identifying my case, as well as formulating my research questions, collecting the material and making ethical considerations, is a constant and interactive process that is taking place parallel to the ongoing analysis. It is not possible to produce an exhaustive account of the activities taking place in a setting - the phenomenon of a researcher's gaze is always seen from a specific angle, with specific perspectives (Hammersley \& Atkinson, 1995). What I have focused on and how the field studies have been conducted are driven by my aim to explore how vocational subjectivities are produced, with a particular focus on how these processes are gendered: in the recruitment and marketing, in the positionings and self-positionings of the participants, and in the speakings and doings of practical learning situations.

Initial field studies, where I visited various educational providers within the beauty industry, led to the formulation of new research questions and rephrasing of old ones. Formulating and rephrasing has continued throughout the field studies, and generated new aspects and more precise categories, during which I have observed occurrences and processes in the field and analysed my material. In the following, I will describe the process of collecting the different types of material, including issues relating to selection, gaining access to the field, and ethical considerations that arose during the research process. The chapter ends with an outlining of my analytical approach, where I discuss my role as a researcher and give a description of the data analysis for each article.

The description of how I collected the material can also be read as a story of how this research project developed, and this might clarify for the reader how the articles were formed and why these particular themes/regularities where chosen at the expense of others. 


\section{Recruitment material}

Early on in the research process, in preparation for the data collection, a general mapping of educational providers operating in the beauty industry was made, using websites, Facebook pages and other information that could be found on the internet. On most websites, additional information materials could be ordered via regular mail. This resulted in me being contacted by several educational providers via e-mail and telephone who were looking to sell me courses and educational programmes. After I started "following” Facebook pages that most of the larger educational providers administer, my Facebook feed featured numerous adverts for various beauty and spa treatments, skin products and courses to sign up for.

After initially going through all of the schools' recruitment and/or marketing material, I started formulating research questions and an aim for the initial study, which focuses on how the student in beauty education is shaped in recruitment/targeted marketing. The recruitment processes that emerged in this material differed significantly from other recruitment processes within adult education, which have mainly focused on the recruitment of people with limited educational achievements and experience (Boshier, 1973; Cookson, 1989; Cross, 1981; Hult, Mäkitalo, Olsson, Paldanius \& Thång, 1997; Lundquist, 1989; Owens, 2000; Paldanius, 2002; Rubenson, 1975). When it comes to the privately run educational providers of the beauty industry, the recruitment was more about selling a product - education and training. This aimed to attract people who correspond to the wishes and needs of the establishment with the help of marketing practices. So, these recruitment processes took place in a marketized educational setting. Early in the process, it also became clear how constructions of femininity emerged in the material, through for example pictures, aesthetics and statements in former students' reviews. An analytical process therefore began to explore how the student subject is shaped here, and how gender is at play throughout this process.

In line with the recruitment processes that were being explored, the material was collected through the information channels available for prospective students online. This material consisted of websites that provide information about current courses and programmes. This information often included short reviews from current or former students, chosen by the schools for marketing purposes. Here one can also find links to the schools' websites and their Facebook pages where those existed. These were included in the material, and the school websites constituted the majority of this material. In total, 36 websites, information about the same 36 schools on studentum.se ${ }^{14}$ and 14 Facebook pages were analysed, because these were the pages that were available at the time. I printed the entire material totalling 646 pages, with some pages being more content rich than others.

\footnotetext{
${ }^{14}$ A website that collects information about courses and programmes.
} 


\section{Access}

Since I did not have any previous experience of or connection to these settings, access was a challenge. There are many aspects to keep in mind when designing a field study, but ultimately the level of access obtained will decide the possibility of carrying it out to a great extent. As Hammersley and Atkinson (1995) point out, processes of negotiating access, collecting data and analysing the material overlap to a great extent. In parallel with collecting and analysing the recruitment/marketing material for the first study, I contacted schools and trade organizations to schedule initial meetings and visits. By this point, all types of schools in the beauty industry (as previously described) were relevant, but ultimately the question about selection initially came down to access.

The trade organizations were easy to contact - I was welcome to visit and meet with representatives, and I was provided with information about the educational sphere of the beauty industry. The educational providers were a little harder to approach, especially those that specialized in makeup and styling where I was not given access. But after some time I established contact with two schools providing education and training for skin and spa therapy. After meeting with the principals I was given more or less free access to the activities of the schools. They became so-called gatekeepers and played important roles in providing me with possibilities to collect my data (see Hammersley \& Atkinson, 1995). I was able to attend and observe lessons, conduct interviews with students and have informal chats with students, teachers and other members of the school staff.

\section{Initial fieldwork}

I visited one school on nine occasions, for about three to five hours at a time, to get a clearer view of the operations of the school and the people engaged in it, and to establish a presence and relationships for future fieldwork. Due to my non-existent experience of these settings and the minor difficulty in gaining access, I saw initial, exploratory fieldwork as necessary before planning and performing the main part of the field studies. During these visits, I had a meeting with the principal and more informal conversations with teachers and other school staff when I had the opportunity. We talked about their previous experience before entering into the educational sphere of the industry, important aspects of their work, the skin and spa therapy educational sphere and labour market, the beauty industry as a whole, potential problems and challenges, and much more. These conversations helped me to familiarize myself with the field. I also attended two or three lessons on every visit. These lessons were divided into two types, where some were directed more towards theoretical aspects of the course content, and some were directed more towards the practical execution of the treatments. I learned a lot by attending these lessons. I found it particularly valuable to partake in the practical lessons since they gave me the opportunity to talk to students while they were performing treatments on each other. The processes of embodiment and of subjectivity production that I could observe here 
caught my attention and served as an important starting point in the planning of the later fieldwork. After seven visits, study II was drafted, where I, through performing and analysing interviews with skin and spa therapy students, explore how these students are positioned and self-positioned as professionals.

Gender may affect one's access to information from field research (Dewalt \& Dewalt, 2002), and me being a cis female was most likely a positive thing in relation to gaining access to this field. Especially in regard to my possibilities to perform the observations, and possibly also when it comes to conducting interviews, my gender, and maybe also my age, was an advantage in regard to both being allowed into the field and the extent to which I could get access to actions in the field. Students' bodies are namely exposed to various degrees during the practical lessons, depending on the treatment being performed, and some of my participants would probably be less comfortable having a male researcher on the spot. This was actually expressed by a member of school staff when we initially talked about my possibilities of observing the practical training, where she said that it most likely would not be a problem especially since I am "a young women and all”. My gender probably also made it easier for me to approach the students during the lessons, sitting beside them, making small talk, posing questions - me not seeming to be so different from them, having similar female experiences of bodily maintenance for example. At the same time, having too little distance from the field can pose a problem when performing field studies. In the answers to my questions, my participants might for example describe the reasons for a treatment in less detail if they think I am already familiar with the procedure. Additionally, taking things for granted is also an issue for me as a researcher, since my prior knowledge about an occurrence might lead to me omitting details when writing my field notes. A methodological starting point in this dissertation is however that there is no reality to discover, only discursive practices to identify. Even so, I tried to keep these issues of distance and prior knowledge in mind while performing the fieldwork, asking additional questions for greater detail or clarification, trying to take a step back once in a while and view the situation from a distance, reflecting on my methodological approach.

\section{Semi-structured interviews}

In study I, which focuses on how the student subject is shaped in recruitment/marketing, regularities of description and self-description emerged that suggested that the student was shaped through responsibilizing and individualizing processes, and a "femininity of consumption". I was then curious to explore how this discourse operate in the students' own statements about their chosen vocation, the education and training they are enrolled in, and themselves in this sphere. Therefore, I conducted interviews with students enrolled on combined programmes in skin and spa therapy where I ultimately focused on how they are positioned and self-position as professionals in terms of knowledge, taking gendered aspects of these processes into account. 


\section{Participants}

The students that I talked to in these interviews all participated in programmes for becoming a skin and spa therapist, programmes that entail about 45-60 weeks of full-time studies. I wished to interview a variety of students regarding age and educational and occupational experience, which would more or less accurately reflect the composition of students at the school. All of the students at the schools had graduated from secondary school since, this is one criterion for entering these schools. All of the students who were asked to participate, except for one, chose to do so. Since I had already spent some time at the school, partaking in both practical and theoretical lessons where I had introduced myself to the class, most of the students knew who I was beforehand. In consultation with the principal and/or teachers at the schools, we decided that I could perform the interviews during the students' practical training in the school salon (where they receive clients from outside). There were almost always one or two of the students who had a free period during this time, or who were in charge of the laundry and/or cleaning and making sure that the tools and products used in the salon were in order. They could often find the time to get away for 30 to 50 minutes to take part in an interview. Therefore, the student that had some free time on each occasion was asked by the teacher or the student who just been interviewed by me if she wanted to go and talk to me and get more information about the study before deciding to participate. The selection of interview participants was thus guided by which student was available at any given moment. My initial aim that my informants would reflect the overall composition in the school was achieved to a certain extent in the ultimate selection, although it is hard to make a completely accurate estimation of these circumstances.

All of the participants identified as women, as far as I know, and they were about twenty to fifty-five years old. However, most of the participants were between twenty and twenty-five and about one quarter were older (between thirty-five and fifty-five). They had different backgrounds and different educational and occupational experiences. The participants who were a little older had experienced careers in different fields before deciding to change path, and some had participated in higher education. Only one of the younger participants had academic experience. Most of the younger participants who had occupational experience had worked in the service sector, for example as clerks in a store or waiting tables at restaurants. Some had taken shorter courses in the beauty sphere, while others had taken some other shorter post-secondary course. Some had also been travelling and/or had worked abroad for a while. After having conducted interviews with about seventeen participants, I noticed that the material had started to lack in variation and I could identify regularities reoccurring ways - through which the participants were positioned and selfpositioned. I interviewed a couple more students and the number of informants ultimately came to twenty.

As described, the skin and spa therapy labour market offer jobs that are low-paid, part-time employment is common and there are commission-based salaries. Some of the participants however planned to start their own businesses in the long run, and some planned to work in the business-side of the industry 
later on - at companies focused on beauty and skin care. They planned to work as skin and spa therapists for a couple of years to gain practical experience of the industry before proceeding to other positions.

\section{Interviews}

The interviews were conducted in the form of formally arranged meetings. However, the informal conversations that took place in my first encounters with the field, and in the participant observations, are viewed as a part of the observation data (see Hammersley \& Atkinson, 1995). The participants were usually interviewed individually; however, at their own request, they occasionally participated in self-selected friendship pairs. These interviews were semi-structured (Kvale \& Brinkmann, 2009). Since I wanted to explore how the participants are positioned and self-position, I wanted to be flexible, letting the participants steer the conversation to some extent. The participants' answers often led to supplementary questions from my end, asking them to clarify a statement and/or describe something in more detail. In this way, the material that stemmed from these interviews was collected through the interaction between myself, as a researcher, and my participants (see Kvale \& Brinkmann, 2009). The questions were formulated with the purpose of encouraging the participant to reason about the issue at hand, provide longer descriptions and give examples of specific occurrences. At the same time I guided the conversations, taking the overall aim of the dissertation and the specific study into account. The interview guide was slightly adjusted after the first two interviews, where I learned to rephrase questions that seemed to be steering the conversation in an unintended direction. As described, I already had prior knowledge about the field knowledge that I obtained through my initial visits and meetings. This knowledge was required when planning and conducting the interviews, and worked to my advantage in my ability to ask supplementary questions (see Kvale \& Brinkmann, 2009).

The interview protocol covered open-ended questions that were divided into five themes around which relevant supplementary questions could be addressed. After informing the participants about the study and the conditions for taking part, I initially asked them about their reasons for entering this VET programme. This question led to supplementary questions that gave me a clearer picture of the person in front of me: her educational and occupational experience, her view of the vocation before entering the VET programme, and her plans and dreams for the future. I then switched my focus to the operations of the school where I asked how they would describe the activities and practices taking place at their school (to somebody who does not know much about this vocation, as well as in more detail). This conversation often led to deeper descriptions about the participants' views of these operations, and also of their vocational choice in relation to people in their surroundings. Examples of how they would describe this VET programme to an outsider often entailed stories about justifying their vocational choice in relation to family, friends and acquaintances they meet in the street. I then moved on to the issue of how the teachers guide the participants in their learning and processes of becoming - a conversation that often provided 
me with descriptions of ideals about the skin and spa therapy professional and how to live up to them. These descriptions overlapped with the next theme, which addressed the issue of school staff guiding the students in how they should be and act during their time at the school, i.e. during their learning processes. In the last theme, my questions addressed how a successful skin and spa therapist acts and is in terms of skills and prosperities and revisited the questions about how this can be learned.

A research interview is a somewhat strange social situation, and the unequal power relation that arises between interviewer and informant is an issue in all interview research (Lillrank, 2012; Kvale \& Brinkmann, 2009). It is a professional conversation initiated and defined by the researcher, whose aim and interest decides on the subject of the conversation, which in many ways can be viewed as a one-way dialogue. The researcher also holds the interpretative prerogative of the informants' statements in the interviews (Kvale \& Brinkmann, 2009). People often want to be accommodating and do a good job. This might, knowingly or unknowingly, lead to a situation where the informant makes statements that he or she thinks are in line with what the researcher wants to hear. During the interviews I therefore initially underlined that there are no right or wrong answers and that I do not have a clear idea about what they might say, but rather an interest in their own personal way of viewing things. I also made social efforts to make the situation less intimidating and my informants more comfortable. However, this is a balancing act and such efforts might lead to a course of events where the researcher guides the informant through the interview, showing opinions and sharing experiences that might affect the informant's statements. This balancing act was on my mind in the process of conducting the interviews. Namely, I realized after the first couple of interviews that my will to establish a relaxed and pleasant interview situation for my informants might be intruding on the correctness of this professional conversation. As Kvale and Brinkmann (2009) acknowledge, performing a qualitative research interview of a high quality requires practice. The knowledge, skills and ability to assess social situations that are needed for this task are largely tacit and require practical experience. The issue of handling the interview situations professionally while still contributing to a pleasant atmosphere, making the informants comfortable, became easier throughout the process of conducting the interviews.

All interviews were audio-recorded, giving me space to focus on the interview itself, and later transcribed. I also took some notes during the interviews on things to follow up on later on in the conversation. Transcribing a recorded conversation has been described as a translation from a spoken language into a written one, and is associated with a series of choices (Hammersley, 2010; Kvale \& Brinkmann, 2009). I was careful to take the same approach when I transcribed all of the interviews. I wrote down the statements literally and included the often-reoccurring events, such as "mm". I also made notes of laughter, ironic tones, imitations, sighs etc. since I view (emotional) expressions and ways of speaking as a part of the material. The interviews were therefore transcribed soon after the interview session so that I could have a clear memory of this meeting. Pauses were also noted, but not in any great detail as it 
did not seem necessary for performing the analysis accurately. When I selected specific quotes later on in the research process as exemplars of the regularities found in the material, I rewrote them in the more formal character of written language. This was done to increase readability, but first and foremost for ethical reasons. Namely, spoken language can more often than not appear incoherent and confusing, and to publish such quotes can, as Kvale and Brinkmann put it (2009, p. 204), "lead to an unethical stigmatization of specific persons or groups."

\section{Observations}

After exploring constructions of the student in recruitment and of how the students are positioned and self-position as professionals through their own statements, I proceeded to conduct observations of situations in practical training. The focus for these observations was planned on the basis of my initial field studies, where I talked to teachers and principals, and attended lessons, both practical and theoretical. These first observations gave me an understanding of occurrences, speakings and doings in the school, and gave me an idea about how to define the focus for future observations in a more structured way, in relation to the general aim of this dissertation. I decided to direct my gaze towards the learning processes taking place in the interaction of the practical training, specifically when and where the participants' own bodies become a tool for learning. These formally conducted observations were performed on 16 occasions that lasted for about two to three hours (but were, as described, preceded by initial, exploratory fieldwork).

\section{Practical lessons}

In the practical training, the lessons usually start with the teacher demonstrating the treatment at hand in front of the class, having a volunteer student playing the role of the client. Afterwards, the students are divided into pairs and take turns practising the treatment on each other, alternating between posing as a therapist and posing as a client. In this way, they get to use various products and practice treatments, as well as experiencing them as a client. Their own body thereby becomes a tool for learning in a double sense. It was clear from a first glance at these activities that they hold complex and extensive processes of becoming that are intertwined with gender and power.

Even if the treatments vary considerably in content, they all begin with the (posing) therapist making an assessment of the state of the (posing) client's body and its details, depending on which treatment is being performed (skin, nails and cuticles, eyebrows, body hair growth, fitness, firmness, smoothness etc.). In this assessment, bodily imperfections are noted and documented, and a treatment plan, including recommendations about products, treatments, diet and exercise, is prepared and communicated to the (posing) client. During the treatment, the students communicate feelings and the experience of performing the tasks and

\footnotetext{
${ }^{15}$ Translated from Swedish by the author.
} 
having the tasks performed on them. The teacher(s) usually walk around the classroom, overseeing the activities, giving instructions and being available for students' questions throughout the session.

In selecting which practical lessons to attend, I strived for variation in treatments being practiced and tasks being performed, since I wanted to collect a rich material that could provide me with an ample understanding of the phenomenon. I communicated this wish to my contacts at the schools and had the opportunity to attend the different practical lessons available. I attended sessions where manicure, massage, various sorts of facial treatments, diathermy, IPL, waxing, pedicure, various types of body treatments and spa treatments were performed. This provided me with a material rich in variation because of the different tasks being performed, and a deeper understanding of the processes of becoming that were taking place here.

\section{Performing the observations}

When it comes to how I carried out the observations more practically, the course of action can be described as participant observation. Participant observation is often described as the foundation method in fieldwork (Schensul, Schensul \& LeCompte, 1999) and refers to a way of collecting data in naturalistic settings, finding out about activities and interactions "as one of the means of learning the explicit and tacit aspects of their life routines and their culture" (Dewalt \& Dewalt, 2002, p. 1). The roles one can assume as a researcher in a participant observation can be placed on a scale between less and more participation (Hammersley \& Atkinson, 1995). I was not a full participant in the observed arrangements, nor was I strictly an observer. Since the students were scattered all over the classroom during the practical lessons, I needed to walk around amongst them, and every now and then approach them more closely to be able to perceive the speakings and doings taking place. It was therefore not possible to go unnoticed, to be "a fly on the wall". However, at the beginning of each lesson when the teacher was demonstrating a treatment surrounded by the rest of the class, and me standing together with them, I could be more strictly an observer.

Occasionally, when the number of students led to uneven pairs, I was asked to step in and pose as a client. On these occasions it was easier to blend in and more naturally have informal conversations with the participant performing the treatment. I also felt I achieved a higher level of confidence from participants and teachers through contributing to the educational arrangement in this way. In field studies, there is always a risk of getting to close to the people being observed, which raises questions of ethics and of upholding a proper distance from the field. This was a balancing act in my interactions with the participants. However, since I performed my field studies at two schools and in different classes, observing several different groups of people, I rather viewed the level of distance as a bigger challenge than getting to close to my field.

During my first visits I found it difficult to physically position myself in the classroom. The practical lessons can be quite hectic with a lot of things going on at the same time. I initially struggled with what to focus on, and at the same time tried not to get in the way. However, after a couple of visits this became 
easier and I found a way to approach the field that felt appropriate for the task. Interactions between the posing therapists and the posing clients, and between teachers and students, were my main focus. I therefore alternated between shadowing the teacher as she (it was always a she) walked around and interacted with the students and by observing the student pairs separately. I occasionally asked a student pair if I could sit down beside them and observe what they were doing, and since I am an outsider when it comes to these settings, I sometimes asked questions to understand the situations more clearly.

I brought a notebook to every observation occasion, in which I openly took notes throughout the sessions. I usually alternated between listening, observing and interacting on the one hand, and pulling back, sometimes to a corner of the room, to quickly scribble down my observations, on the other. Thus, the notes were often made during shorter periods of time throughout the sessions. After completing the observation session for the day, I left the school and wrote down my notes more thoroughly on my computer. This was done as soon as possible, usually in a café near the school. On these occasions, I supplemented the notes while I wrote them down on my computer, producing richer descriptions of the situations described. When I selected specific parts of the field notes later on in the research process as exemplars of the regularities found in the analysed material, I often added information about the situation at hand to increase readability.

It is probably not possible to observe something and not at the same time make an interpretation of it, and this interpretation needs to be clear from demonstrations of opinions, judgements or valuations of people or occurrences (Arvastson \& Ehn, 2009). This is one of the ethical issues that I have taken into consideration in this dissertation, and that will be elaborated on in the following.

\section{Scope of material}

To sum up the scope of the research material on which this dissertation is based, I have here included a short summary of what it consists of.

\begin{tabular}{|l|l|}
\hline $\begin{array}{l}\text { Recruitment/marketing } \\
\text { material }\end{array}$ & 646 printed pages from the internet \\
\hline Initial observations & 23 hours \\
\hline Interviews & $\begin{array}{l}20 \text { participants, 30-50 minutes, } 111 \\
\text { transcribed pages }\end{array}$ \\
\hline $\begin{array}{l}\text { Formally conducted } \\
\text { observations }\end{array}$ & 40 hours \\
\hline
\end{tabular}

\section{Ethical considerations}

The study follows the ethical principles developed by the Swedish Research Council (Vetenskapsrådet, 2002), which entail that informed consent was 
obtained from the participants, that I strive for confidentiality/anonymity, that the material is kept in a safe place and that it is used only for the purpose of research.

Submitting information about the purpose of the research is described in the field study tradition as a delicate balancing act between very detailed information, which might strongly guide the participant in a certain direction, and fundamental parts that could be important for the participant to be aware of. However, in a poststructural approach, this balancing act is not of importance since there is no reality outside of discourse to discover. The information about the study given to the participants is, however, important ethically. My approach can, in line with the field study tradition, be described as open (see Hammersley \& Atkinson, 1995) and being totally transparent is a difficult quest since the aim of the specific study might be adjusted during the research process (Kvale \& Brinkmann, 2009). When I told my participants about the study I therefore described the aim of my research in broad terms and at the same time pointed out that I find it important to be flexible in relation to what the material might show. In the case of the interviews, I told the gatekeepers and my informants that I am interested in the processes of learning and becoming that take place in the school that are not necessarily written down in the curriculum. I also pointed out that I am interested specifically in their view of these matters. Regarding the observations, I explained that I was interested in the learning processes taking place in the interaction of the practical training, and where the participants' own bodies become a tool for learning.

In the case of the interviews, it was however difficult to control how the information about the study was initially given and received, and if the volunteer circumstances for taking part were underlined. As described in the interview section, the participants were usually first asked by their teacher or fellow classmate. Of course, I got the chance to uphold informed consent and point out the volunteer circumstances for participating before conducting the interviews. However, I got the impression at times that the students thought it was the school administration's will that they should take part. (Being "good" students and following school rules seemed important.) I was thus extra careful to underline that it was perfectly voluntary and that they could decide to withdraw their participation at any time or choose to pass on particular questions.

Regarding the observations, I gave a short presentation in front of the class at the beginning of the lesson I planned to participate in and observe. Here, I told the class who I was and described the general aim of my research together with the ethical guidelines I acknowledge, underlining the volunteer circumstances for participating. The students then had the chance to ask questions, and I also made sure they were aware of the possibility to ask questions and/or withdraw their participation during the session. During these occasions, the students seemed positive towards participating in the study. This could however not be guaranteed, since I did not get a verbal "yes" from everybody, nor did I repeat this information in front of the whole class if I visited the same group of students on another occasion. When I performed the observations I therefore, when walking around the classroom and when I approached students more closely, made sure once again that everybody was comfortable with my presence. When I 
came to the same class, I also asked if there was anybody there who had not heard my presentation, so that I could fill them in.

I have followed up on the issue of confidentiality during the writing process, in descriptions of the setting where the research took place and of the participants, as well as in quotes and field notes included in my texts. The names are fictionalized, and I have not connected any other personal features, like age, ethnicity or details of somebody's appearance, to quotes or field notes in order to anonymize the data. Such features are not relevant to my results, since the focus in the analysis is on the regularities that can be identified in the material.

In addition to these more clearly defined ethical guidelines, other ethical considerations have been made continuously throughout the research process. As Kvale and Brinkmann (2009) point out, a researcher must learn to use his or her common sense to become ethically competent instead of simply and mechanically following a set of rules. Reflected choices have been made while designing the study, gaining access to the field, performing the fieldwork, and analysing the material and presenting the results - verbally and in text. For example, a qualitative interview - the interaction between interviewer and participant - is filled with ethical issues, which is also the case in observations and other types of field studies. Interview-based research is dependent on the social relationship between interviewer and participant - that the participant feels secure enough to share private thoughts. Performing a qualitative interview therefore requires a balance between one's own interest as a researcher to obtain valuable knowledge and being respectful towards the participant's integrity (Kvale \& Brinkmann, 2009). Ethical considerations have therefore been made in designing the interview guide and in the choices I faced concerning supplementary questions in the ongoing interview situations. Issues concerning the body, and one's own body in relation to others in particular, can be quite intimate. Therefore, special attention to these issues was required in pursuing this research.

Ethical concerns are also relevant in relation to my role as a researcher, which I will elaborate on in the following section where I describe and discuss the analytical approach.

\section{Analytical approach}

My poststructuralist feminist theorization, which is mainly inspired by Foucault, decides the premises for the analytical process. Unlike some of the other theorists who have focused on the workings of discourses (see e.g. Fairclough, 2003; Potter \& Wetherell, 1987), a Foucauldian approach does not provide any suggestions or set of rules for how an analysis should be carried out. Foucault has argued that his writings can instead be viewed as toolboxes for analysis (Patton, 1979). The poststructuralist concepts presented in the theorization constitute the "toolbox" of my analysis - these are the concepts that have guided me and provided me with a way of answering my research questions. Such theorization can accordingly not be separated from my method. Here, the anti-essentialist 
stand that is significant for a poststructuralist approach is fundamental, and this means that all forms of meaning production in the material are considered as text, including pictures, aesthetics, documented interactions in social media (Facebook), employment adverts, advertisement for treatments and products, interview transcriptions, student reviews, special offers, descriptions of course content, field notes and other occurrences. I adopt a non-hierarchical approach towards all parts of this text (see e.g. Börjesson, 2003); there is no difference between those texts that are represented as literary and those texts that are not (Mills, 1997). The text constitutes the discourse I am exploring; there is no reality outside of this text that we can apprehend. However, the questions I asked of the material in the analysis differ slightly depending on the part of the text at hand, and the specifics of this process are described in the following.

When analysing these multiple power relations, one must put the question of intentionality aside; explicit intentions are not relevant to take into consideration when analysing these multiple relations of power. There is often a gap between intentions and what actually happens, and taking intentions into account risks analysing simple relations of cause and effect. Foucault's interest was rather on analysing contingencies - a focus that enables examinations of the way that power operates (see e.g. Kendall \& Wickham, 1999; Mills, 2003). Thus, instead of examining what the providers of beauty education have intended for their students, and if these intentions were realized, my focus has rather been on the result of the educational arrangements; how student subjectivity is produced, making visible how power operates throughout these processes.

\section{Regularities}

In the analysis, my interest was directed towards relations of power, specifically gender relations of power, and the production of subjectivities in conjunction with and in relation to vocational learning. I have focused on how such processes emerge through regularities of description and self-description. The regularities, i.e. reoccurring events, that we can perceive in reality should be viewed "as the result of the anonymous regularities of discourse which we impose on reality" (Mills, 2003, p. 55). It is not a coincidence that similar ways of handling situations, presenting problems, describing contents (for example) can be identified in the material - these reoccurring events mean something, and they can tell us stories about how power operates if we ask the question of how regularities are made possible, or even desirable.

In the process of identifying regularities, I read and re-read the material, trying to discover recurrences of events, of ways of talking about oneself and others or ways of addressing an issue, for example. I have not counted the number of times the identified regularities appear, but rather focused on how pervasive an identified regularity is and how it relates to other found regularities and the rest of the material - the pattern the regularities produce together, one might say. Ryan and Bernard (2003) conclude that "(y)ou know you have found a theme when you can answer the question, What is this expression an example of?” (p. 87) and like them, even if I do not think about my identified regularities of description and self-description strictly as "themes", though this is a broad 
term, I have had questions similar to the one stated above in mind in the analysis. When I was confronted with a statement, a picture, a course description, an announcement etc., I approached the "event" thinking about if I could describe what it is an example of, and if this description made sense to me when putting it in relation to the rest of the material and any previously identified regularities.

In this process of identifying regularities, I have also posed other questions to the material, questions that differ slightly in the different articles. Common for all questions are however how the text produces ideals - ideals about the student and future worker of this field - how these ideals emerge through discourse and how gender relations emerge as historical effects of power. For example, which subject emerges when the participants talk about the successful skin and spa therapist? How should one be and act, which qualities and skills should one have, and how should one present oneself? In the regularities identified through posing such questions, a caring subject for example emerges, which connects to wider discourses of femininity and caring. Or, when it comes to the recruitment/marketing material, whom does the text turn to - who is the target group? How should one be to fit into the environment (the beauty industry) described? How does power operate in the material? How is, for example, the reader - the target group - governed to become such a subject? In the regularities identified here, the student subject is for example produced through a neoliberal discourse when she (because the subject is also shaped as female) is responsibilized for her own success or failure, thus individualizing the subject at the same time.

\section{Data analysis}

As described, the data analysis was conducted in the same way in all of the articles. I will however give a description below of the analysis for each article in order to paint a clearer picture of the relationship between the different steps of the analysis, their chronological order and how they resulted in the four articles that constitute the empirical part of this dissertation.

In study I, which was performed on the basis of the most extensive material (646 pages printed from the internet), I initially looked and read through the entire material in order to get a sense of how discourse emerged and how discourse was constituted. I used coloured pens to mark out regularities that emerged, some more recurrent than others. This rough analysis resulted in many reoccurring events. I read through the material several times, during which I supplemented the previously identified regularities, making them richer. In this process, it became clear that some of these events were only reoccurring in conjunction with smaller specializations of courses in the field. Furthermore, when I read through the material, I alternately formulated and reformulated my research questions in relation to the overall aim of the dissertation. Some reoccurring events were put aside in favour of others. The study was ultimately limited to exploring how the student is shaped in the material - what is the subject that emerges here and how does it emerge? I thereafter read through the material again in order to discern the discursive processes through which the student is shaped. New regularities emerged here and previously identified ones 
became richer. Is the student subject gendered, and if so how do gender relations of power emerge? Here, I made notes about the reoccurring events that build the discourse. I then read the material again several times to explore these regularities further, after which I divided them up in groups. Taking these groups of regularities and the aim of the study as a starting point, the discourse emerged - a structure for describing the processes I could discern from the material.

In the case of study II, which is based on my interview material, the general aim became clearer from the beginning. My gaze was now directed towards how students were constructed as professionals, as vocational subjects. In the analysis, I carried out a first read-through without coding or marking out particular quotes, to get a more general idea and overview of the material. I then read through the transcriptions more careful to discern the regularities of description and self-description - the reoccurring ways through which the students are positioned and self-position, as vocational subjects (see e.g. Fejes \& Haake, 2013; Foucault, 1988a). I now used coloured pens to mark out regularities, reoccurring events, in the material. Some statements were marked with several colours. (The different colours symbolized different ways of describing these reoccurring events, and different ways that they related to each other.) After working my way through all of the transcriptions, I had a number of questions in mind in this process. How do the students present themselves, and how do they present themselves as future professionals? How do they talk about the vocational sphere and future work life? Which knowledge emerges in these stories, and how are particular discourses mobilized? How does power operate in the material? I went back and started again. After this rough analysis, I specified the aim of the study, where I set out to explore how skin and spa therapy students are positioned and self-position as professionals in terms of knowledge, and how gender is at play throughout this process. I then read through the material repeatedly to further explore the regularities that emerged and to consider reasonable interpretations and ways of organizing them. In the process of identifying regularities, I often compared identified regularities within the same "group" to each other, and here I was able to identify regularities within regularities. This helped me to make sure that the regularities I chose to further explore were deeply rooted in the material. I then collected the regularities that build the discourse, whereupon a structure for describing these processes emerged.

The analyses in studies III and IV were somewhat intertwined, where both were based on the interview material as well as field notes from observations in practical lessons in skin and spa therapy education. I focused on processes of embodiment in the learning situations that I could discern in the material, but still with an ultimate focus on the formation of subjectivities. As stated above, the focus on processes of embodiment stemmed from my initial field studies, where I more informally took part in lessons and other activities in schools as well as talking informally to students, teachers, principals and other school staff. The interviews also gave me an idea about the extensive processes through which student bodies are engaged in the educational arrangements. It was obvious that bodies - one's own and the bodies of fellow classmates - played an important 
part in the process of becoming a professional in this sphere. However, I made the judgement that the interview material alone was not enough to grasp these processes - I needed to observe practical learning situations were bodies played an important part, and initially I planned on only using field notes for the exploration of embodiment.

After performing the observations, I read through the field notes and analysed them roughly. Processes of embodiment were extensive and occurred in various ways. I read the material repeatedly to discern regularities of processes of embodiment, and these regularities were roughly divided into categories, marked by coloured pens. In the selection of which categories to explore further, I turned to my previous analysis of the interview transcripts and also included this material when I compared identified regularities to each other. Regularities found in the observation material could also be identified in the interview material, and I decided to broaden the material and also include the interview transcripts.

Two distinctive ways through which processes of embodiment emerged could then be identified in this material: firstly, through the production of bodies in the learning processes; and secondly, how the students are produced as emotional workers in learning processes surrounding the body. I started out by exploring the production of bodies in the learning processes through exploring the identified regularities further. What body emerges in the material - how is it produced? Through which processes is it produced, and how are these processes powered and gendered? What kind of professional subject emerges in the production of bodies in these educational arrangements? The participants are here, for example, positioned and self-position as self-aware and responsible in relation to bodies: Self-aware about the shortcomings and needs of one's own body, and responsible for achieving the appropriate and professional level of bodily maintenance. Like previous articles, the material was read repeatedly, regularities of description and self-description were identified, these regularities were reviewed and compared to each other, and a structure for describing these processes emerged.

When it comes to study IV, I initially wanted to explore how the students talk about and handle "sensitive" situations surrounding the body, and how they handle feelings that these might evoke, in the material. I sought to understand these processes in relation to the vocational learning and the becoming of a professional - an appropriate worker - in this sphere. I therefore set out to explore how the students are produced - how they are positioned and selfposition - as emotional workers in learning processes surrounding the body. What kind of emotional worker emerges in the production of the ideal learner and ideal future worker in skin and spa therapy? Emotional work had already emerged in the project when I explored how the students are positioned and selfposition through a caring discourse (article II), but the emotional work I could discern here was not that specific but corresponded well to emotional work detected in other caring vocations, such as practical nursing. Here, however, I wanted to visibilize the emotional work specific to the skin and spa therapy setting, and I therefore focused on situations surrounding the body. I set out to explore the situations surrounding the body that were produced as sensitive, or 
problematic, where the student had to overcome feelings of pain, discomfort or embarrassment. I read the material repeatedly in order to identify such regularities, coded the material using coloured pens, comparing groups of regularities to each other, and a structure for describing these processes emerged. I found three reoccurring issues surrounding the body; the body as a place of pain, the body as a private sphere, and discomfort and disgust in relation to bodily occurrences. I then continued the analysis to explore how the participants are positioned and position themselves as emotional workers through these situations. How do they present themselves through acting in a particular way? Which feelings do they express and how do they talk about these feelings in relation to their future job role and how to handle these feelings? Here, for example, tough and enduring subjectivities emerge. Thus, this analysis was carried out in two larger steps where I first identified reoccurring issues/situations surrounding the body, and then explored how the participants are produced through these issues/situations.

\section{Reflexivity of the researcher}

As described, ethical considerations are present in the entire research process. One such aspect, which also concerns issues of the validity and quality of the analysis, is my own role in the research process. Since researchers are highly involved in constructing their studies - and the knowledge it generates - it is of great importance to apply a critical perspective on one's own knowledge claims, an activity called reflexivity. Adopting reflexivity also entails that the theoretical frameworks applied should be discussed in relation to one's own research practice (Börjesson, 2003; Kendall \& Wickham, 1999; Ramazanoğlu \& Holland, 2002; Winther Jørgensen \& Phillips, 2000). The poststructuralist theorization has consequences for how one can view research and the role of the researcher; the researcher is here viewed as being a part of the discourse he/she is exploring. To describe something totally truthfully is in a poststructuralist study, inspired by Foucault, not relevant since there is no reality outside of discourse. Instead, I am, in the procedure of collecting and analysing the material, forming a structure for the processes I find - and discourses emerge through this procedure. Even when I initially formulate and delimit my study, I operate within discursive formations, from a subject position as a researcher (see e.g. Börjesson \& Palmblad, 2007). Here, in similar ways to my participants, I become both a product and a producer of discourse. I am also involved in the simultaneous process of becoming both product and producer in the collection of the material. The field notes have been formed through my ethnographic focus and my way of documenting the observed events (see Arvastsson \& Ehn, 2009). The semi-structured interview is the product of an interplay that I, together with my informants, have contributed to forming (Kvale \& Brinkmann, 2009). Through a poststructuralistic view, one can however argue that the discourse allows me to produce a structure with these specifications. How this research comes to be is a consequence of what is made possible and should therefore be viewed as historically and culturally specific; in every time and place, there are a limited number of ways to interpret and present 
something and still be considered as reasonable (Börjesson, 2003). My produced text is therefore part of the construction of the phenomenon studied, and the text is simultaneously a product of discourse. This should however not be considered as inhibitory, but as the very premise for doing analysis in the first place (Börjesson \& Palmblad, 2007).

Drawing on feminist theory in my exploration of the educational sphere of the beauty industry involves me in the relationship between feminism and the beauty industry. I here contribute to the discursive construction of such a relationship, and to what position this discourse should be assigned in social and educational science (see Fejes, 2006). In the research process, I initially wanted to go beyond the obvious feminist critique but remain critical in an approach where I take the empirical material as a starting point. Empirical research on the beauty industry namely illustrates that what goes on here is far more complex than is commonly understood (Black, 2004; Black \& Sharma, 2001; Gimlin, 1996; Kang, 2003; Toerien \& Kitzinger, 2007). I have therefore, as described, tried to keep an open mind in relation to my material, letting my theorization guide the research process.

\section{Quality and trustworthiness}

As discussed, there is no reality outside of discourse. Therefore, it is not reasonable to discuss issues relating to quality in terms of validity, though it suggests that there is such a thing as an objective and generalizable truth. This does not mean however that one can write anything - there are still rules defining good quality. Instead of speaking about validity, quality is discussed in terms of trustworthiness (Denzin \& Lincoln, 2017, p. 98). This trustworthiness is dependent on the researcher's clarifications and problematizations concerning theorization and methodology, including issues of reflexivity (Börjesson, 2003; Winther Jørgensen \& Phillips, 2000). The reader can then assess if the analysis and arguments the researcher is making seem reasonable (Howarth, 2000), or, as Dean (1999) writes, that "the present account should be judged in terms of its coherence, clarity, completeness and, above all, capacity to convince” (p. 10). 


\section{SUMMARIES}

All four papers in this dissertation have focused on the production of vocational, gendered subjectivities in private adult education for the beauty industry: how future students are shaped in recruitment, how skin and spa therapy students are positioned and self-position as professionals in terms of knowledge, the production of bodies in skin and spa therapy training, and the production of students as emotional workers. Using different sorts of empirical data, although with all sorts viewed as text, all papers draw on a poststructural feminist perspective inspired by Foucault.

The first paper is a product of my first encounter with the field, where I attempted to map out the landscape of beauty education in Sweden by reading the information I could find on the internet. The material that this information formed contained many things, but it was mainly its function of recruiting students through marketing practices that caught my eye. How is the student subject shaped here? I decided to examine the issue of student subjectivity further in the second paper by interviewing contemporary students at schools directed at skin and spa therapy education - one of the most common specializations in the field of beauty education. How is student subjectivity constructed when the students themselves are positioned and position themselves through their own statements? This focus allowed me to examine in more depth how student subjectivity is constructed in terms of knowledge, and how this process is intertwined with gender relations of power. In the two remaining papers I decided to turn my attention towards aspects related to bodies - aspects that I recognized as an inevitable part of the learning processes - the processes of becoming - in this field. I performed observations at schools directed towards skin and spa therapy education, and these field notes form, together with the transcriptions of the previously conducted interviews, the material for the last two papers. The third paper scrutinizes the production of bodies in skin and spa therapy education and training. How are bodies produced when participants are positioned and position themselves in classroom interaction and interviews? The fourth paper focuses on how students in skin and spa therapy education and training are produced as emotional workers. I had touched upon the subject of emotional labour (see Hochschild, 2003) in the first paper, and had found that this aspect was of great importance for further examination within the framework of this dissertation. In order to examine how specifically skin and spa therapy students are produced as emotional workers, I focused on how they are produced as emotional workers in learning processes surrounding the body. 


\section{Paper 1: Shaping the female student: an analysis of Swedish beauty school recruitment texts}

Bredlöv, E. (2016). Studies in Continuing Education, 38(2): 243-258.

\section{Eleonor Bredlöv}

Department of Behavioural Science and Learning, Linköping University, Sweden.

The aim of this study was to explore the processes through which student subjectivity is shaped in recruitment to private beauty education in Sweden. The issue of recruitment has been an important theme within adult education research (see, e.g. Hult et al., 1997; Lundquist, 1989; Owens, 2000; Paldanius, 2002), but has mainly focused on how to enrol people with limited educational achievements in educational programmes. Through focusing on a highly commercialized part of the educational sphere - beauty education - different recruitment practices are examined. Drawing on a poststructural approach inspired by the work of Foucault and tools provided by feminist theory, the shaping of student subjectivity in recruitment material for private beauty schools was analysed. The data collection focused on the information channels available to students online, and the research material includes the websites of beauty schools, beauty schools' Facebook pages and websites that compile information on beauty education. All forms of meaning production in the material are considered as text, including for example pictures, advertisements, student reviews and descriptions of course content.

The results showed how student subjectivity is shaped through responsibilizing and individualizing processes where the student is constructed as a participant in the market for education, free to make her own choice, yet responsible for making the right one. Furthermore, student subjectivity is shaped through constructions of femininity - she is competitive, she has clear goals and she is prepared to adopt a tough attitude to reach these goals. The student is also shaped as a consumer in different ways. One way is that the student is shaped as a responsible consumer of education, and this consumer behaviour can be viewed in terms of responsibly shaping one's life through acts of choice, in this case choices of consumption. This results show clear indications of the shaping of the entrepreneurial self, where the relationship that is established with one's self takes on an "enterprise form" through a neoliberal discourse (Edwards, R., 2002; Rose, 1996, 1999a, 1999b). The relationship with one's self then becomes the basis for a number of investment decisions concerning, for example, education, employability and one's appearance. At the same time as the student is shaped as a responsible consumer, she is also constructed as a capricious consumer through discourses of femininity. A femininization of consumption is here adopted by the predominant discourses of marketization and operates as a resource for the shaping of student subjectivity. The student is also shaped as a seller and marketer of the same products and treatments she is expected to consume. To 
succeed, one should also engage in the marketing of oneself. A regular occurrence in the examined text is how student subjectivity is shaped through blurred boundaries between work/school and leisure - a theme that cuts through the previous sections.

The paper discusses how constructions of femininity are made a central issue in these recruitment activities, where a particular form of the gendered entrepreneurial self is produced. Education is here positioned as a process through which (female) students are invited to become those who will promote the financial success of particular beauty companies, thus becoming part of the market, or instruments of it, as they act to constitute and extend it.

\title{
Paper 2: Constructing a professional: Gendered knowledge in the (self-)positioning of skin and spa therapy students
}

\author{
Bredlöv, E. (2016). Gender \& Education, 29(7): 890-906.
}

\section{Eleonor Bredlöv}

Department of Behavioural Science and Learning, Linköping University, Sweden.

Taking skin and spa therapy education and training as a starting point, the aim of this study was to outline the self-positioning of students in private beauty education. More specifically, it focused on how they position themselves as professionals in terms of knowledge and, considering the femininized context, how gender is at play throughout this process. Drawing on a poststructural approach, inspired by Foucault and feminist theory, regularities of description and self-description were analysed. This approach provides analytical tools for analysing how people engage with discourse in this micro-context of education and training, and feminist theory enables an understanding of how gender relations of power emerge. The material consists of interview transcripts derived from interviews with twenty skin and spa therapy students.

The results show how gender relations of power emerge in the selfpositioning of the participants. A scientific professional emerges through a masculine discourse of scientifically based knowledge, and how a caring professional emerges through caring dispositions that connect to wider discourses of femininity. The caring professional is partly constructed through a conflation of caring for together with caring about, and an appreciation of a pleasure of giving, which can be viewed as a productive power that constructs positive emotions as a form of capital, thereby legitimating the low financial gain in choosing this line of work. The self-positionings that centre around both scientifically based knowledge and caring dispositions often emerge in opposition to a stereotyped image of the beauty business as a whole, which is mainly constructed in terms of foisting unnecessary beauty products on customers and fomenting an obsession with one's appearance. Through this 
stereotyped image, particular beauty worker femininities are placed in subordinate positions. However, things that are constructed as complicating the credibility of the business, such as selling activities and aspects of beauty, emerge in the student's self-positioning through a caring discourse. The study tells a story about how students in an educational setting, which is placed within a highly constraining and delegitimizing set of gender relations, carve out a space for themselves to operate as respectable professionals. The paper discusses how a caring discourse ultimately is being mobilized and a stereotyped image of the beauty industry is shown to govern students' self-positioning, reproducing norms of gender and consumption.

\section{Paper 3: Learning a critical gaze: Producing gendered bodies in skin and spa therapy education and training}

Manuscript published online in Journal of Vocational Education and Training, doi: https://doi.org/10.1080/13636820.2017.1394354

Eleonor Linder Eknor

Department of Behavioural Science and Learning, Linköping University, Sweden.

This study scrutinized the production of gendered bodies in skin and spa therapy education and training. More specifically, the aim was to examine how bodies are produced when participants are positioned and position themselves in classroom interaction and interviews. Drawing on a post-structural approach, inspired by Butler, regularities of description and self-description were analysed. This approach provided analytical tools for analysing how people engage with discourse in this micro-context of education and training, and enabled an understanding of how these processes are gendered. The material consists of field notes derived from observations of practical lessons in vocational programmes for skin and spa therapy (on 16 occasions that lasted for about two to three hours each), and interviews with twenty skin and spa therapy students.

The results show how these educational arrangements enact a process where the students learn to adapt a critical gaze towards bodies - the bodies of clients, future and present, as well as their own. In the roleplay of the practical training, where the participants pose as clients themselves, they become aware of their bodily 'deviations' and which products, treatments and lifestyle choices they need to adopt and consume; they rediscover their body. Here, the participants position themselves through self-awareness and responsibility - a process of self-governing that produces bodies that are respectably feminine. Through disciplining themselves, the participants also govern each other when norms about how to relate to one's own body in this educational setting are produced (see Foucault 1983, 2007). In the interactions taking place in the practical training, the participants are also disciplined in becoming more self- 
aware and responsible in more direct ways, by the teacher or classmates. Bodies are produced as biological entities that are unruly and - if left without discipline and correction - imperfect. At the same time, the imperfect body is produced through and producing normativity, offering alternative ways of producing normative femininity, alongside naturalizing skin and spa therapy consumption and activity.

The paper discusses how a medical (scientific) discourse is being mobilized that pathologizes the body, making skin and spa therapy treatments curing. The body, which is produced as flawed, is pathologized at the same time as it is produced through normativity - two contradictory processes that both reinforce the existence of the skin and spa therapy business.

\section{Paper 4: Becoming an emotional worker of bodies: Exploring skin and spa therapy education and training}

Manuscript submitted for publication

\section{Eleonor Bredlöv Eknor}

Department of Behavioural Science and Learning, Linköping University, Sweden.

Inspired by the term "emotional labour", coined by Hochschild (2003), the aim of this study was to outline how skin and spa therapy students are positioned and self-position as emotional workers in learning processes surrounding the body. I found it of great importance to explore the specifics regarding emotional work when it comes to skin and spa therapy education. I therefore choose to direct my focus towards processes surrounding the body. Drawing on a poststructural approach, inspired by Foucault, regularities of description and self-description were analysed. The material consists of field notes derived from observations of practical lessons in vocational programmes for skin and spa therapy (on 16 occasions that lasted for about two to three hours each), and interviews with twenty skin and spa therapy students.

The results show how tough and enduring subjectivities emerge, striving to overcome the obstacles that one's body and one's feelings and reactions might entail in the process of becoming a professional. Three reoccurring issues surrounding the body emerge as such obstacles; the body as a place of pain, the body as a private sphere and the body as a changeable and unpredictable entity with the ability to evoke discomfort and disgust. In the process of overcoming these obstacles, the participants are produced as responsible for their learning process, and the levels of skin care that success within this sphere entail. Communicative and responsible subjects also emerge, taking responsibility for the learning process of one's classmates through communicative actions and making one's body available for practice. These processes of emotion work surrounding the body emerge as processes where beauty, normativity and 
occupational success play a central role, and as inevitable in order to operate in this sphere.

The paper discusses implications for further research on emotional labour. In addition to an emotional worker, an emotional student emerges when the participants are produced as learners, pinpointing the necessity for further educational research on emotional labour. Implications for further VET research on emotional labour are also discussed. 


\section{DISCUSSION}

The overall aim of this thesis was to answer the question: "How are vocational, gendered subjectivities produced in vocational education for the beauty industry?" This question is answered in four articles that all focus on the production of vocational, gendered subjectivities in private education for the beauty industry. The first article focuses on subjectivity production (in recruitment) over the whole spectra of vocational titles connected to the beauty industry, and the other three articles dig deeper into the processes of becoming in skin and spa therapy education and training specifically. Different aspects of subjectivity production are made visible and explored throughout these articles: How the potential beauty student is shaped through responsibilizing and individualizing processes (through a femininity of consumption) in recruitment, how a scientific and a caring professional emerges in the (self-)positionings of skin and spa therapy students, producing gender relations as effects of power, how students learn to adapt a critical gaze towards bodies wherein they position themselves as self-aware and responsible through femininity, and how students are produced as emotional workers, taking Hochschild's term "emotional labour" as a point of departure. So, overall, what can be said about the vocational and gendered subjectivities that emerge here? I will first briefly discuss the results in relation to the posed research questions, and thereafter I will discuss the results more widely, together with the research process, concluding with implications for future research.

\section{Results revisited}

Skin and spa therapy education and training is an example of an educational sphere that is strongly segregated by gender, and, as previous research has shown, the beauty industry in itself is filled with feminine connotations (Black, 2004; Gimlin, 1996; Scranton, 2001). This alone can be said to enact processes of self-selection, producing the ideal skin and spa therapy worker as feminine in particular ways, resulting in processes of becoming that include emotional and relational aspects, beauty consumption, activities of self-care, and appropriate bodily displays. Furthermore, constructions of femininities in relation to this particular field cannot be separated from market forces, since a femininity of consumption is found to govern student subjectivity. The student is for example, as I have illustrated, constructed as a consumer (and seller) of beauty products (and treatments), which is enacted through the product adverts and how the beauty worker is constructed as well-groomed and normatively beautiful. A process is enacted through recruitment/marketing and educational practices where (female) students are invited to become instruments of the market.

One of the research questions put a focus on how the processes, through which subjectivities are produced, are enacted in the educational settings, 
including the recruitment to these settings. In my analysis (foremost articles 3 and 4) I illustrated how subjects emerge through processes of responsibilization. This is partly done through the educational arrangements, the practical training, where students are responsible not only for their own learning process, but also for the learning processes of their fellow classmates. When students learn to assess their classmates' bodies, and when they are produced as emotional workers, the learning taking place is produced as a collective process in which all participants are involved. The interaction between the students, one posing as a client and the other posing as the skin and spa therapist, is produced as a condition for this learning taking place. It is somehow paradoxical how students on the one hand are produced as individual achievers and on the other as subjectivities whose ability to cooperate is important for the greater good that is a fruitful, well-functioned, effective, collective process of practical training. What brings these processes of individualization and collectivization together is, however, the responsibilization where the ideal student is ascribed prosperities of being a good co-operator. She is then becoming an emotional worker capable of handling the relational aspects of her future work, in client relationships as well as in relationships with colleagues. Developing relational capabilities, taking pleasure from working together, and appreciating the pleasure of giving can therefore be understood as a rational choice made by an active subject (Edwards, R., 2002; Rose, 1999a).

The educational arrangements around skin and spa therapy education and training also enact processes where subjectivities are constructed that establish particular relationships to bodies - others and one's own. Self-aware subjectivities are constructed when students critically assess their fellow classmates' bodies as well as their own - they rediscover their body in terms of having deviations. This body is pathologized through a medical discourse and the search for deviations, and thereby in need of products and treatments, producing student subjectivities as self-aware consumers of beauty. Through these relationships to bodies, tough and enduring subjectivities emerge, which are important features in order to become ideal and effective emotional workers. These relationships are also important in order to become a consumer of the skin therapy sphere, where the pathologized, yet normalized, body requires subjectivities to be tough, overcoming the obstacles that their bodily reactions, and the feelings that these evoke, constitute.

Another of the research questions concerned issues of what makes the production of the professional skin and spa therapist possible, and even desirable. Here, I argue, scientific knowledge becomes central. The production of a scientific professional is made possible through wider discourses of what makes "real" and "true" knowledge in our societies, which are produced through gender relations of power. This is a desirable position, although it automatically gives rise to increased legitimacy, constructing this vocational choice as a reasonable choice, investing in one's future and increasing one's social status. Together with the responsibilizing and individualizing processes identified in the first article how skin and spa therapy students are produced as self-aware and responsible concerning their body, its flaws and its required skin care identified in the third 
article, and the responsible ways that participants are produced as emotional workers and learners shown in the fourth article - responsibilization can definitely be described as a dominant process in the subjectivity productions identified. I would like to return to the shaping of the entrepreneurial self ${ }^{16}-\mathrm{a}$ dominant way of constructing the self in Western democracies that we have come to understand through the work of Rose and others (Edwards, R., 2002; Rose, 1996, 1999a, 1999b). Operating within a neoliberal discourse, the relationship that is established to one's self becomes generalized to all forms of conduct (Rose, 1999a). Edwards (2002, p. 357) highlights the importance of responsible consumption in subjectivity production and argues that particular cultural values and norms constitute the starting point in "the shaping of conduct", and individuals are here taken as active subjects. In relation to the results of this dissertation, the entrepreneurial self becomes the basis for the consumption of beauty products - and the bodily maintenance that such consumption entails and educational programmes and courses, responsible choices that, in relation to Edward's argument, can be viewed as made possible by the historically, socially and culturally specific values and norms of our society. Such a way of thinking can also be related to aspects of these processes of becoming that are not directly linked to consumption. The participants responsibly discipline themselves when they learn to embody the professional skin and spa therapist, correcting their tone of voice, strengthening their posture and monitoring the speed of their movements, when they learn to handle their feelings and how to induce feelings in others in order to become a professional. This embodiment, becoming an emotional worker, a "team player" and an individual achiever, can all be viewed as responsible choices made by active subjects, made possible through the cultural values and norms of this time and place. In this way, a particular form of the gendered entrepreneurial self is shaped in this femininized educational context.

A caring professional is also made possible, and desirable, through wider discourses of respectable (see Skeggs, 1997) femininity. These professionals have learned to appreciate the pleasure of giving, which is easily related to Hochschild's (2003) study of flight attendants where she concludes that “Seeming to 'love the job' becomes part of the job; and actually trying to love it, and to enjoy the customers, helps the worker in this effort" (Hochschild, 2003, p. 5). The caring professional (identified in article 2) and the emotional worker (identified in article 4) are both made possible, and desirable, through dominant discourses of femininity and motherhood (see Skeggs, 1997). The nurturing woman - the mother - can be viewed as a controlling image through which femininity is constantly imitated and repeated (see Butler, 1990). Furthermore, the caring and relationally skilled professional is also made possible by rejected femininities; when the caring professional emerges, it is in opposition to a beauty worker who wants to foist products and treatments on customers, and who is too preoccupied with looks and beauty. Through such a negative image of the beauty industry, particular femininities are rejected and others are taken up as possible,

\footnotetext{
${ }^{16}$ Indications of "the entrepreneurial self” are briefly discussed in the first article.
} 
and desirable. In this way, the negative image of the beauty industry and its workers can be viewed as a controlling image - the discourse of a greedy and vain beauty industry governs the way that participants are positioned and position themselves as professionals, even though this discourse is actively rejected. This process can be related to the balancing act one has to be able to manage to achieve normative femininity (see e.g. Ambjörnsson, 2004; Eduards, 2007). ${ }^{17}$

A responsibilized subjectivity also emerges through recruitment practices. Such practices are enacted through marketing activities online, where the beauty student is produced through individualizing and responsibilizing processes, where the student is given full responsibility for one's success or failure. Working in the beauty industry is portrayed as desirable. Success is within reach if you put your mind to it and work hard. In other words, the beauty sphere is described as a high status dream - a goal worth working hard to reach. The paradoxical tendency of both responsibilizing the educational consumer - the potential student - and addressing the reader as a whimsical, capricious consumer (similar to how mainly female consumers are addressed in consumer society in general) contributes to the construction of a desirable, high-status product - enrolment in the programme. Thus, neoliberal discourses and a femininity of consumption make these subjectivity positions possible, and even desirable.

Furthermore, becoming a critical assessor of bodies and a self-aware and responsible beauty consumer is made possible, and desirable, through a femininity of consumption and the production of (female) bodies as biological entities that are unruly and-if left without discipline and correction - imperfect. The imperfect body is at the same time produced through normativity, inviting everyone to take part in skin and spa therapy treatments - promoting the survival and development of the industry. Particular relationships to bodies, others and one's own, are also made possible through wider discourses of femininity where a women's value is closely connected to her appearance and the degree to which her appearance correlates with contemporary norms about feminine appearance.

\section{Dominant discourses of science and excluded knowledges}

Discourses of science are mobilized when the participants are positioned and self-position, as shown in the second and third articles. I will here discuss how the skin and spa therapy vocation specifically, and other vocations more generally, might be conditioned by the dominance of scientific knowledge.

\footnotetext{
${ }^{17}$ To achieve normative femininity has been described (see e.g. Ambjörnsson 2004; Eduards 2007) as a balancing act between 'the lesbian, unfeminine woman' on the one hand and 'the whore' (that one risks being positioned as having too much focus on creating a feminine look) on the other. This balancing act emerges in the material when the participants are forced to navigate in this landscape of power relations, emerging as historical effects of power, for becoming respectable (see Skeggs, 1997).
} 
Namely, in the construction and development of vocations, scientific knowledge emerges as dominant in the story of what counts as "true".

In the second article, I examined how skin and spa therapy students are positioned and self-position as professionals in terms of knowledge. Here, a scientific professional emerges through a (masculine) discourse of scientific knowledge, and a professional also emerges through caring dispositions, connecting to wider discourses of femininity. The participants are positioned and self-position through scientific knowledge in stories of when they explain their vocational choice to family, friends and acquaintances they meet in the street. Descriptions of "real" subjects such as anatomy, chemistry, biology and mathematics are here used as resources in the production of this educational choice as a reasonable choice, and this process is strongly gendered. Descriptions of what people seem to think about the skin and spa therapy sphere are imbued with feminine connotations. ${ }^{18}$ The skin and spa therapy sphere is constructed as unserious through femininity, and is then re-produced as legitimate and "real" through scientific knowledge, producing gender relations as historical effects of power.

So, the way that discourses of scientific knowledge are mobilized here produces gender relations as historical effects of power - a process that conditions the way that the skin and spa therapy vocation is produced by students and used as a resource in their (self-)positionings as professionals. Scientific knowledge has also conditioned the way that other vocations and professions have been constructed and developed. Henriksson (2001) writes:

\footnotetext{
In its narration the male physician's occupation is the prototype and model for all developed occupations. It controls and sets boundaries to the development of other occupations, as well as excludes many other actors. Medicine is the center of the field and its profession the yardstick. (p. 305)
}

So, according to Henriksson, it is not just scientific knowledge in general that conditions the way that vocations are produced, but medical knowledge specifically. These processes are operationalized through inclusion and exclusion. Mills (1997) refers to Fairclough (1992), drawing attention to the process through which medical science has been given, and maintained, authority over what is considered as "true". Here, extensive efforts are put into ensuring that "alternative" knowledge about health is considered as inferior and amateurish. Drawing on Foucault, this can be seen as the result of power struggles, namely, discourses are in constant conflict with other discourses over questions of truth and authority (Mills, 1997). In the production of the professional in skin and spa therapy education, it is constructed as true that the "real" knowledge this professional holds is scientific knowledge, connecting to a medical discourse and wider discourses of rational masculinity (see e.g. Löwy, 1999; Kourany, 2002; Connell, 2005, Waerness, 1996; Rose, 1994; Maynard, 1997). Furthermore, when participants are positioned and position themselves

\footnotetext{
${ }^{18}$ Through statements such as "girls sitting around fiddling with nails, not doing anything real.”
} 
through caring dispositions, these dispositions are not constructed as "knowledge" but as personal characteristics through femininity.

Discourses of medical knowledge are also mobilized in the third article, where I examine how bodies are produced when the participants are positioned and self-position in the interactions of the practical training. Here, I identify a process where the participants learn to adopt a critical gaze towards bodies, wherein (female) bodies are pathologized, which produces correcting treatments as curing treatments. These processes normalize and legitimate skin and spa therapy activity through medical discourses.

When medical knowledge has "won" the discursive struggle of what is true, what knowledge, in relation to beauty education, has then been put aside? As described, caring dispositions are not constructed as knowledge, in line with previous research concerning the professional status of practical nurses (see e.g. Skeggs, 1997; Fejes \& Nicoll, 2010), and it is of course extremely important that this issue is highlighted and that the knowledge it takes to do emotional labour and care work is recognized as knowledge, both for educational purposes of effectiveness and so that these knowledges are remunerated properly. But are there additional knowledges in the beauty sphere that are not acknowledged in the production of the professional skin and spa therapist? There might be a kind of, maybe, aesthetic knowledge and/or handicraft skill one must have, to be able to follow practices such as putting on makeup successfully. ${ }^{19}$ I would like to return to an excerpt used in the second article to illustrate how caring dispositions are put forward as important. Here, a participant is specifying what she means when she says that it is important "to have a feeling for it":

To be able to handle people is of course important, and then that you have a certain feeling for doing things since you after all, I mean, are dyeing eyebrows, you do touch people, you give massages, that you have a sort of... that is what I mean by having that instinctive feeling. You need to have a feeling for how you take care of people. That is what I mean. (Interview no. 5)

Here, skin and spa therapy activities are produced through a caring discourse when the participant concludes: "You need to have a feeling for how to take care of people." Dyeing eyebrows might however require some other type of knowledge, besides relational capabilities and chemical knowledge about the dyeing product - maybe knowledge and skills to be able to determine which colour to use? Then to shape eyebrows must require handicraft skills and aesthetic skills. These knowledges and skills do not emerge as a regularity in my material as a part of the successful skin and spa therapy professional's knowledge. One might suspect that this has something to do with power. Foucault (1980) writes:

...one should understand something else, something which in a sense is altogether different, namely, a whole set of knowledges that have been

\footnotetext{
19 The few vocational programmes in skin therapy that are included at secondary school are located within the Handicraft programme, not in the Health and Social Care programme.
} 
disqualified as inadequate to their task or insufficiently elaborated: naive knowledges, located low down on the hierarchy, beneath the required level of cognition or scientificity. (p. 82)

It is important to scrutinize how discourses of medical knowledge are mobilized when vocations and professions are constructed and developed, as well as how additional knowledges are discredited or simply made invisible. One must be aware of such processes, and other power struggles that are at play in the formation of new vocations/professions and the development of existing ones.

These are important results that should be of great interest for the beauty industry in general and the skin and spa therapy field in particular. The analysis of how power is at play in the construction of professional knowledge uncovers how such processes inform the way that beauty workers are positioned and position themselves as professionals, processes that it is important to be aware of in the re-development of professional identities in the field. Such processes of power might also be at play in the attempts to regulate the industry in Sweden. As proposed, procedures that require medical knowledge and experience and that entail considerable risks (like fillers and Botox), should be performed by medical professionals (SOU 2015:100). This proposal has been developed together with representatives from the industry, and it is also important to note that these treatments (fillers and Botox) are not included in traditional skin and spa therapy education and training. The proposals have however been heavily criticized by several of the referral bodies and are not regarded as sufficient to be the basis for legislation. The critics demand that additional treatments, such as diathermy, IPL and chemical peels, should be regulated and only be performed by medical professionals. ${ }^{20}$ So, critics argue that the medical sector should get involved in the skin therapy field to a greater extent. If one believes that professional skin therapists are not equipped to perform such treatments, then why is the conversation not directed towards a development of their vocational education and training? I would argue that this development can, just like my results, be seen in the light of gender relations of power and how they inform the way that "real" professional knowledge is formed and developed, and in this case, relocated.

\section{Unpredicted aspects of beauty ideals}

As implied in the chapter on previous research, there is a substantial lack of gendered perspectives in VET research, even though the research that does exist has shown strong implications for such research. During my initial university studies, before I became a $\mathrm{PhD}$ student, my interest was directed towards issues concerning gender and other social categories, and how they interplay in different fields of society, in the production of identities and in relation to various phenomena. When I then became a PhD student, I wanted to direct this interest

\footnotetext{
${ }^{20}$ The National Board of Health and Welfare has been appointed to investigate these issues further, and will present the results of this mission by September 30, 2018 (the Government Offices of Sweden, 2017).
} 
towards the day-to-day activities of educational and vocational spheres to explore how power is at play in processes of becoming. Given this interest, I wanted to examine identity formation, taking gender into account, in a specific vocational sphere, through field studies. I found the educational sphere of the Swedish beauty industry to be particularly interesting given my interest. In my mind at the time, beauty industry workers can be said to work at the front line when it comes to ideal appearances of femininity, somehow implementing contemporary beauty ideals in their work. Or, maybe they oppose these unattainable ideals, creating new, alternative ways of approaching the issue? During the analysis in my first article $^{21}$, the market forces at play caught my eye. Promises about beauty were of course made in adverts selling products (sometimes at a discount if one enrols in an educational programme) and courses, appealing to the reader's hopes, dreams and desires. Through such adverts, the student is produced as a female consumer, a process through which a femininity of consumption is being mobilized. Women are to a greater extent than men judged by their appearance in our society broader discourses of femininity say that girls and women ought to care about their appearance, they should (must!) desire beauty and they are even responsible to at least try to be as (normatively) beautiful as they can be. Anything else is perceived as incomprehensible, or as an act of resistance. Here, beauty is produced as the higher unmentioned goal one can reach through consuming products and knowledge - a result in itself - but beauty ideals are produced just as in consumer society as a whole, and it did not make sense to scrutinize these ideals further in this study.

Then, I proceeded to explore student subjectivity formation in programmes for skin and spa therapy through field study. My expectations of being able to examine how people in this field handle beauty ideals were not fulfilled in the way that I had in mind. Instead, beauty and beauty ideals remained unmentioned and elusive, as something that goes without saying, present as an overall regime, governing the activities taking place and formulating the reasons for their performance. As described in relation to the second article, the participants self-position as professionals through scientific and caring knowledge, in opposition to a negative, stereotyped image of the beauty industry. This image is mainly constructed in terms of foisting unnecessary beauty products on customers and fomenting an obsession with one's appearance. However, the caring professional ultimately emerges as a resource in legitimating skin therapy activities tied up with beauty and selling. In society in general, using products and performing treatments are no longer necessarily seen as strivings for beauty - these activities are now re-packaged as self-care. And so, such a development is also noticeable in my material when a caring discourse is mobilized when participants are positioned and self-position as professionals. In the third article, I show how the (female) body is pathologized in the very same process as it is produced through normalization, promoting skin and spa therapy consumption. Through these processes of

\footnotetext{
${ }^{21}$ In this article, I examined how the student is produced in recruitment to beauty education.
} 
pathologization, correcting treatments ${ }^{22}$ can rather be thought of as curing, as treating an illness. Thereby, products that are designed for highlighting beauty can now be thought of as products of self-care. This way of thinking about these activities produces the beauty industry as something more compatible with feminism and with individualized ideals of self-realization, and it is fair to say that this has given rise to a further upswing for the beauty industry, both financially and culturally. This can however be seen as a re-negotiation of norms that actually legitimize the mobilization of a femininity of consumption, and further inform gender relations of power.

So, given the overall aim of the study, the theorization and methodology, the material collected and the analysis made, I was able to explore beauty ideals in terms of how the participants engage with discourse in order to re-position themselves as beauty workers through caring dispositions. Furthermore, in relation to future clients, performing correcting treatments and enhancing clients' normative beauty were produced as being relevant only if this correlated with the clients' wishes. Strivings for beauty are therefore produced through processes of individualization, giving the individual the freedom to choose if and, in such a case, which beauty norms to conform to, yet responsibilizing the individual. Namely, such a process connects to the contradictions that are associated with advanced liberal governing when it comes to freedom. As, drawing on Foucault, subjectivities are positioned and self-position in a simultaneous process of selfregulation, the seemingly free individual, promoted by neoliberalism, is actually responsibilized (Rose, 1999b).

So, the production and reproduction of beauty ideals were not examined to any great extent. Instead, other processes (such as the ones described above) were considered as dominant in relation to processes of becoming; It was not the beauty ideals in themselves that were interesting in relation to processes of becoming, but the way that students in this educational setting engage with discourse in ways that make it possible for them to operate as respectable professionals.

\section{Future research}

As described, there is a substantial lack of gendered perspectives in VET research, even though the research that does exist has shown strong implications for such research. In this dissertation, I have focused on a vocational sphere strongly associated with femininity. However, processes of becoming informed by gender relations of power can (probably) be identified in any other vocation, including vocational and professional spheres that can be said to have an equal gender representation.

The results of this dissertation show how the participants are produced as emotional workers in particular ways, which are skills that are not recognized or remunerated to any great extent. The care and emotion work that women

\footnotetext{
${ }^{22}$ Described in Black (2004) as treatments correcting a bodily occurrence that does not correspond well with normative femininity, such as so-called embarrassing hair growth, acne or cellulites.
} 
perform, and the caring dispositions one must develop to be able to perform this work successfully, are often unacknowledged and undervalued, since they is often reduced to skills that are natural for women, to skills that women automatically gain in their experience of being female (Nay \& Garratt, 2002). Pierce (1995) show how there is a gender-differentiated delivery of emotional labour among paralegals, where women paralegals are expected to give lawyers tremendous amounts of support, while male paralegals were not expected to be nurturing and were also included in professional gatherings, being treated as though they were preparing for law school. Gendered aspects of emotional labour can also affect whether the tasks confirm workers' sense of gender identity (Steinberg \& Figart, 1999). Stenross and Kleinman (1989) examined emotional labour in relation to police detectives and sheriff interrogators, where detectives viewed themselves in terms of solving crimes, which entailed more intellectual aspects of the job, constituted by them as "real detective work" (p. 441). More relational aspects of the job, requiring more extensive emotional labour, were by implication less "real". They therefore "defined their work in terms of its more masculine characteristics and expressed dislike for the feminine work of caring" (Steinberg \& Figart, 1999, p. 17). Thus, they positioned themselves as professionals through wider discourses of masculinity. Research on emotional labour is mainly found within sociological research, where emotional labour in worklife has been the main focus, and there is a surprisingly low frequency of VET research problematizing emotional labour. Given my results and a review of the VET literature, more focus on the learning of emotional labour might help to uncover hidden knowledges and processes through which students' and workers' gender identity might inform their job performance, their vocational knowledge and skills, the extent to which they are remunerated for their work, and, overall, processes of becoming in VET. As shown in this study, students become (successful) emotional workers through learning processes more or less enacted in the vocational arrangements. Such processes also need to be outlined properly in order to develop strategies for education and training to prepare students for the labour market and working life in a particular vocation.

Moreover, my results show how the participants in skin and spa therapy education and training are produced not only as emotional workers, but also as emotional students, taking responsibility for their fellow students' learning process through communicative acts. These acts emerge as inevitable in order to proceed through the training, and crucial in the processes of becoming a professional in this sphere. These results call for further research on emotional labour in learning environments in general, not only in VET. Specifically, students are produced as emotional workers when they operate as learners. More knowledge is required to generate an understanding of how such relational abilities interconnect in various learning processes. My results also show that the performance of emotional labour is gendered, which should be acknowledged in future educational research on the subject.

The beauty industry has struggled with issues concerning professional status (Black, 2004; Toerien \& Kitzinger, 2007), which have been connected to the beauty versus brains dichotomy and to gender relations of power (Black). 
Beauty workers have been categorized as feminine in particularly derogatory ways. In this study, it is clear that the processes through which the participants are positioned and self-position are conditioned by the low status of skin and spa therapy work. The story that emerges is also a story about gender relations of power and how such relations emerge as historical effects, which circumscribes how knowledge and vocations are produced. This particular industry and its educational sphere has not been scrutinized to any great extent, and I cannot help but think that the lack of VET research can be seen in the light of the low status of the industry, not acknowledging these vocational categories as "real". I believe that a wider view of what VET research should include would be fruitful to develop our understanding about how occupations are formed through knowledge, and might even include relatively new occupational titles that do not require formal education. Some examples of this are found among those occupational titles that have arisen in the wake of the emergence of social media, for example.

The beauty industry is represented in the publicly financed educational sphere, but is for the most part found in the private sector, which has probably also affected the emergence of research in this field. Taking the first article as a point of departure, it is clear that market forces are at play when the ideal student is constructed. For example, the ideal student is constructed as loyal, and therefore constructed as belonging more to the educational company than to the self. Given the marketization and commercialization of the Swedish educational sphere, it has become even more relevant to scrutinize how market forces might condition processes of becoming and how new and old vocational titles are formed, or re-formed in relation to the economic sectors of vocations. The marketization of the Swedish educational sphere has been examined substantially in relation to compulsory school and upper secondary school (see e.g. Böhlmark \& Lindahl, 2007; Dahlstedt \& Fejes, 2018; Erixon Arreman \& Holm, 2011a, 2011b; Lundahl et al., 2013;), and some research has focused on the marketization of adult education (Fejes, Runesdotter \& Wärvik, 2016). I, however, given the results from this study, see a need for more research focusing on the relationship between the development of VET and the economic sector of the specific industry. As described, the Swedish National Agency for Education makes all decisions concerning higher vocational education (HVE), analysing demands for a qualified workforce and allocating funding to educational providers. Actors in the labour market are however invited to have some influence, affecting how VET in HVE is formed and how vocations are constructed and developed.

As noted in the description of the beauty industry at the beginning of this dissertation, there is a process of attempting to regulate the beauty industry and demands for a "properly" educated work force (see e.g. SOU, 2015:100). This process can be understood as a discursive struggle where medical knowledge is constructed as the "real" knowledge, a knowledge that can only be obtained properly in the educational programmes for doctors, medical nurses, dentists and dental hygienists - "real" educational programmes. So, the medical sector might be in the position of entering new parts of the beauty industry (maybe not 
surprisingly at the same time as the industry is experiencing a boom). This process is not only a discursive struggle about what is "real" knowledge, it also has strong implications for being classed, gendered, and informed by market forces. Important research about the development of vocational knowledge in VET therefore involves scrutinizing how the "beauty industry problem", and solutions to this problem, is formulated in policy documents and by referral groups. 


\section{REFERENCES}

Allan, H. T. \& Smith, P. A. (2005). The introduction of modern matrons and the relevance of emotional labour to understanding their roles: developing personal authority in clinical leadership. International Journal of Work Organization and Emotion, 1(1): 20-34.

Ambjörnsson, F. (2004). I en klass för sig: genus, klass och sexualitet bland gymnasietjejer. Diss. Stockholm: Univ.

Arvastson, G. \& Ehn, B. (red.) (2009). Etnografiska observationer. 1st ed.Lund: Studentlitteratur.

Bates, I. (1991). Closely observed training: An exploration of links between social structures, training and identity. International Studies in Sociology of Education, 1(1-2): 225-243.

Beck, V., Fuller, A. \& Unwin, L. (2006). Safety in stereotypes? The impact of gender and "race" on young people's perceptions of their post-compulsory education and labour market opportunities. British Educational Research Journal, 32(5): 667-686.

Berglund, I. (2009). Byggarbetsplatsen som skola - eller skolan som byggarbetsplats?: en studie av byggnadsarbetares yrkesutbildning. Diss. Stockholm: Stockholm University.

Bettio, F. \& Veraschchagina, A. (2009). Gender segregation in the labour market: root causes, implications and policy responses in the EU. Luxemburg: Publication Office of the European Union.

Black, P. (2004). The Beauty Industry: Gender, Culture, Pleasure, 1st ed. London: Routledge.

Black, P. \& Sharma, U. (2001). Men are real, Women are “made up”: beauty therapy and the construction of femininity. Sociological Review, 49(1): 101-116.

Blau, F. D., Ferber, M. A. \& Winkler, A. E. (2006). The Economics of Women, Men, and Work (5th ed.). Upper Saddle River, NJ: Prentice Hall.

Bordo, S. (1990). Reading the slender body. In M. Jacobus, E. Fox Keller, \& S. Shuttleworth. (eds.). Body/Politics: Women and the Discourses of Science (pp. 83-112). New York: Routledge and Kegan Paul.

Boshier, R. (1973). Educational participation and dropout: A theoretical model. Adult Education, 23(4): 255-282.

Brotheridge, C. M. \& Grandey, A. A. (2002). Emotional labour and burnout: Comparing two perspectives of "people work.” Journal of Vocational Behavior, 60: 17-39.

Butler, J. (1990). Gender Trouble: feminism and the subversion of identity. New York: Routledge.

Butler, J. (1993). Bodies that Matter: on the discursive limits of "sex". New York: Routledge. 
Butler, J. (1997). The Psychic Life of Power: theories in subjection. Stanford, Calif.: Stanford Univ. Press.

Börjesson, M. (2003). Diskurser och konstruktioner: en sorts metodbok. Lund: Studentlitteratur.

Börjesson, M. \& Palmblad, E. (red.) (2007). Diskursanalys i praktiken. 1st ed.Malmö: Liber.

Böhlmark, A. \& Lindahl, M. (2007). The impact of school choice on pupil achievement, segregation, and costs: Swedish evidence. IZA DP 2786.

Carlbaum, S. (2011). Reforming education. Gendered constructions of future workers. In A. Egan Sjölander and J. Gunnarsson Payne (eds.), Tracking Discourses: Politics, identity and social change (pp. 79-111). Lund: Nordic Academic Press.

Carlbaum, S. (2012). Blir du anställningsbar lille/a vän?: diskursiva konstruktioner av framtida medborgare i gymnasiereformer 1971-2011. Diss. Umeå: Department of Political Science, Umeå University. Available online: http://urn.kb.se/resolve?urn=urn:nbn:se:umu:diva-54360

Closing the Gender Gap: Act Now. (2012). Paris: Organisation for Economic Cooperation and Development (OECD).

Colley, H., James, D., Diment, K. \& Tedder, M. (2003). Learning as Becoming in Vocational Education and Training: Class, Gender and the Role of Vocational Habitus. Journal of Vocational Education and Training, 55(4): 471-498.

Colley, H. (2006). Learning to labour with feeling: class, gender and emotion in childcare education and training. Contemporary Issues in Early Childhood, 7(1): 15-29.

Connell, R. W. (2005). Masculinities. 2nd ed. Cambridge: Polity Press.

Cookson, P. (1989). Recruiting and retaining adult students: A practice perspective. New Directions of Adult and Continuing Education, 41: 3-11.

Christodoulou, M. (2016). Excluded and dropped in: Habitus and biographical identity in vocational adolescents' life transitions. Journal of Vocational Education \& Training, 68(3): 320-341.

Cross, K. P. (1981). Adults as learners: [increasing participation and facilitating learning]. 1st ed., 2. pr. San Francisco: Jossey-Bass.

Dahlstedt, M. \& Fejes, A. (red). (2018). Skolan, marknaden, framtiden. Lund: Studentlitteratur.

Davies, B. (2006). Subjectification: The relevance of Butler's analysis for education. British Journal of Sociology of Education, 27(4): 425-438.

Dean, M. (1999). Governmentality: Power and rule in modern society. London: Sage publications.

Denzin, N. K. \& Lincoln, Yvonna S. (eds.) (2017). The SAGE Handbook of Qualitative Research. Fifth edition. Los Angeles: Sage.

DeWalt, K. M. \& DeWalt, B. R. (2002). Participant Observation: a guide for fieldworkers. Walnut Creek, Calif.: AltaMira Press.

Diamond, I. \& Quinby, L. (1988). Feminism \& Foucault. Reflections and Resistance. Boston: Northwestern Univ. Press.

Du Gay, P. (1995). Consumption and Identity at Work. London: Sage. 
Eduards, M. (2007). Kroppspolitik: om moder Svea och andra kvinnor. Stockholm: Atlas.

Edwards, T. (1997). Men in the Mirror: men's fashion, masculinity and consumer society. London: Cassell.

Edwards, R. (2002). Mobilizing lifelong learning: governmentality in educational practices. Journal of Education Policy, 17(3): 353-365.

Erixon Arreman, I. \& Holm, A-S. (2011a). School as “Edu-business": Four Serious Players in the Swedish School Market. Education Inquiry, 2(4), 637-657.

Erixon Arreman, I. \& Holm, A.-S. (2011b). Privatisation of public education? The emergence of independent upper secondary schools in Sweden. Journal of Education Policy, 26(2): 225-243.

Fairclough, N. (1992). Discourse and Social Change. London: Polity.

Fairclough, N. (2003). Analysing Discourse: textual analysis for social research. New York: Routledge.

Fejes, A. (2006). Constructing the adult learner: a governmentality analysis. Diss. Linköping: Linköping University.

Fejes, A. \& Nicoll, K. (2010). A vocational calling: exploring a caring technology in elderly care. Pedagogy, Culture \& Society, 18(3): 353-370.

Fejes, A. \& Haake, U. (2013). Caring and daring discourses at work: Doing gender through occupational choices in elderly care and police work. Vocations and Learning: Studies in vocational and professional education, 6(2): 281-295.

Fejes, A. (2012). Knowledge at play: Positioning care workers as professionals through scientific rationality and caring dispositions. In H. Hvid and A. Kamp (eds.), Elderly Care in Transition: management, meaning and identity at work: a Scandinavian perspective (pp. 83-106). Frederiksberg: Copenhagen Business School Press.

Fejes, A., Runesdotter, C. \& Wärvik, G-B. (2016). Marketisation of adult education: Principals as business leaders, standardised teachers and responsibilised students. International Journal of Lifelong Education, 35(6): 664-681.

Ferber, M. A. \& Julie A. N. (ed.) (2003). Feminist Economics Today: beyond economic man. Chicago: Univ. of Chicago Press.Finnish National Agency for Education (2000). Grundexamen inom skönhetsbranschen. Utbildningsprogrammet för kosmetolog. Retrieved from http://www.oph.fi/download/110882 skonhetsbranchen_grundexamen_gr under_for_laroplanen.pdf

Foucault, M. (1979). The History of Sexuality. Vol. 1, An introduction. London: Allen Lane.

Foucault, M. (1980). Power/Knowledge: selected interviews and other writings 1972-1977. 1st American ed. New York: Pantheon.

Foucault, M. (1982). The Archaeology of Knowledge and the Discourse on Language. 1. Pantheon paperback ed. New York: Pantheon books. 
Foucault, M. (1983). Afterword. The subject and power. In H. L. Dreyfus \& P. Rabinow (eds.). Beyond Structuralism and Hermeneutics (pp. 208-226), 2nd ed. Chicago: Chicago University Press.

Foucault, M. (1988a). Technologies of the self. In L. Martin, H. Gutman, \& P. Jutton (eds.), Technologies of the Self: A seminar with Michel Foucault (pp. 16-24). Amherst: Univ. of Massachusetts Press.

Foucault, M. (1988b). Critical theory/intellectual theory, interview with Gerard Raulet. In L. D. Kritzman (ed.), Politics, Philosophy, Culture: interviews and other writings, 1977-1984.

Foucault, M. (1990). The History of Sexuality. Vol. 1, The will to knowledge. Harmondsworth: Penguin.

Foucault, M. (1993). Diskursens ordning: installationsföreläsning vid Collège de France den 2 december 1970. Stockholm: B. Östlings bokförl. Symposion.

Foucault, M. (1995[1977]). Discipline and Punish: the birth of the prison. 2nd Vintage Books ed. New York: Vintage Books.

Foucault, M. (2007). Security, Territory, Population: Lectures at the Collège de France 1977-1978. Houndmills, Basingstoke, Hampshire: Palgrave MacMillan.

Fraser, K. M. (1999). Same or Different: Gender politics in the workplace. Aldershot: Ashgate.

Gimlin, D. (1996). Pamela's Place. Power and Negotiation in the Hair Salon. Gender \& Society, 10(5): 505-526.

Gordon, S., Benner, P. \& Noddings, N. (eds.) (1996). Caregiving: readings in knowledge, practice, ethics, and politics. Philadelphia, Pa.: Univ. of Pennsylvania Press.

Gordon, S. (1996). Feminism and caring. In S. Gordon, P. Benner, Patricia and N. Noddings (eds.) Caregiving: readings in knowledge, practice, ethics, and politics (pp. 256-277). Philadelphia, Pa.: Univ. of Pennsylvania Press.

Government Offices of Sweden (2017). Regeringen vill se starkare skydd vid skönhetsingrepp. Retrieved from http://www.regeringen.se/pressmeddelanden/2017/10/regeringen-vill-sestarkare-skydd-vid-skonhetsingrepp/

Grandey, A. A. (2000). Emotion regulation in the workplace: A new way to conceptualize emotional labor. Journal of Occupational Health Psychology, 5(1): 59-100.

Grimshaw, D. \& Rubery, J. (2007). “Undervaluing women’s work”, European Work and Employment Research Centre, Univ. of Manchester, Working Paper Series, No. 53, Equal Opportunities Commission, 2007.

Gåfvels, C. (2016). Skolad blick på blommor: formandet av yrkeskunnande i floristutbildning. Diss. (summary) Stockholm: Stockholm University, 2016.

Hammersley, M. \& Atkinson, P. (1995). Ethnography: principles in practice. 2nd ed. London: Routledge.

Hammersley, M. (2010). Reproducing or constructing? Some questions about transcription in social research. Qualitative Research, 10(5): 553-569. 
Heikkinen, A. (2001). Masters and mistresses of the nation. In P. Gonon, A. Heikkinen \& K. Haefeli (eds.), Gender Perspectives on Vocational Education (pp. 215-228). Bern: Peter Lang.

Henriksson, L. (2001). Gendering the theories on professions - five narratives. In Gonon, Philipp (red.), Gender Perspectives on Vocational Education: historical, cultural and policy aspects (pp. 305-329). Bern: Peter Lang.

Hertzberg, F. (2007). Gymnasievalet och bilder av framtiden på en etniskt delad arbetsmarknad. In Dahlstedt, M. (red.), Utbildning, arbete, medborgarskap. Strategier för social inkludering i den mångetniska staden (s. 127-156). Umeå: Boréa.

Hochschild, A. R. (2003 [1983]). The Managed Heart: commercialization of human feeling: Twentieth anniversary edition with a new afterword. 2nd ed. Berkeley, Calif.: Univ. of California Press.

Holland, J., Ramazanoğlu, C., Sharpe, S. \& Thomson, R. (1994). Power and desire: the embodiment of female sexuality. Feminist Review, 46: 21-38.

Howarth, D. (2000). Discourse. Buckingham: Open Univ. Press.

Hult, H., Larsson, S., Mäkitalo, Å., Olsson, L.-E., Paldanius, S. \& Thång, P.-O. (1997). Varför avstår arbetslösa från studieplats i kommunal vuxenutbildning? University of Gothenburg: Department of Education and Special Education.

Högberg, R. (2009). Motstånd och konformitet: om manliga yrkeselevers liv och identitetsskapande i relation till kärnämnena. Diss. Linköping: Linköping University.

Imdorf, C., Reisel, L. \& Hegna, K. (eds.) (2015). Gender Segregation in Vocational Education. Bingley: Emerald Group Publishing Limited.

Jones, G. (2010). Beauty Imagined: a history of the global beauty industry, Oxford: Oxford Univ. Press.

Kang, M. (2003). The managed hand. The commercialization of bodies and emotions in Korean immigrant-owned nail salons. Gender \& Society, 17: 820-839.

Kemisk-Tekniska Leverantörsförbundet (2016). Statistik. Retrieved from: http://ktf.se/statistik/

Kendall, G. \& Wickham, G. (1999). Using Foucault's Methods. Thousand Oaks, Calif.: Sage.

Klope, E. (2015). I skuggan av ett yrke: om gymnasieelevers identitetsskapande på hantverksprogrammet frisör. Licentiatuppsats i didaktik, Stockholm: Stockholm University.

Kourany, J. A. (2002). The Gender of Science. Upper Saddle River, NJ: Prentice Hall.

Kupfer, A. (2014). The interrelation of twenty-first-century education and work from a gender perspective. International Studies in Sociology of Education, 24(1): 113-125. doi:10.1080/09620214.2014.895142.

Kvale, S. \& Brinkmann, S. (2009). Den kvalitativa forskningsintervjun. 2nd ed.Lund: Studentlitteratur.

Lederman, M. \& Bartsch, I. (2001). The Gender and Science Reader. London: Routledge. 
Lehmann, W. \& Taylor, A. (2015). On the role of habitus and field in apprenticeships. Work, Employment \& Society, 29(4): 607-623.

Lenz Taguchi, H. (2014). In på bara benet: en introduktion till feministisk poststrukturalism och subjektivitetsteori. 2nd ed. Malmö: Gleerup.

Lewis, S. (2003). The integration of paid work and the rest of life. Is postindustrial work the new leisure? Leisure Studies, 22(4): 343-345.

Liljekvist, Å. (2012). Rum för rörelse: om kroppens bildning och utbildning $i$ skolans gymnastiksalar. Diss. Stockholm: Stockholm University, 2013.

Lillrank, A. (2012). Managing the interviewer self. In Gubrium, J. F (ed.), The Sage Handbook of Interview Research: The complexity of the craft (pp. 281-294). Thousand Oaks: Sage.

Lundahl, L., Erixon Arreman, I., Holm, A. \& Lundström, U. (2013). Educational marketization the Swedish way. Education Inquiry, 4(3): 497-517.

Lundquist, O. F. (1989). Studiestöd för vuxna: utveckling, utnyttjande, utfall. Gothenburg: Diss. University of Gothenburg.

Löwy, I. (1999). Gender and science. Gender \& History, 11(3): 514-527.

Mariskind, C. (2014). Teachers' care in higher education: contesting gendered constructions. Gender \& Education, 26 (3): 306-320.

Mayer, C. (2001). Transfer of concepts and practices of vocational education and training from the center to the peripheries: The case of Germany. Journal of Education and Work, 14(2): 189-208.

Maynard, M. (1997). Revolutionizing the subject: Women's studies and the sciences. In M. Maynard (ed.), Science and the Construction of Women (pp. 1-14). London: UCL Press.

McLaren, M. A. (2002). Feminism, Foucault, and Embodied Subjectivity. Albany: State Univ. of New York Press.

McNay, L. (1992). Foucault and Feminism: Power, gender and the self. Cambridge: Polity Press.

Meyer, M. H. (red.). (2000). Care Work: gender, class, and the welfare state. New York: Routledge.

Msiska, G., Smith, P. \& Fawcett, T. (2014). Exposing emotional labour experienced by nursing students during their clinical learning experience: A Malawian perspective. International Journal of Africa Nursing Sciences, 1: 43-50.

Mills, S. (1997). Discourse. London: Routledge.

Mills, S. (2003). Michel Foucault. London: Routledge.

Nay, R. \& Garratt, S. (2002). Nursing Older People: issues and innovations. Sydney: McClennan and Petty.

Niemeyer, B. \& Colley, H. (2015). Why do we need (another) special issue on gender and VET? Journal of Vocational Education \& Training, (67)1: 110.

Noddings, N. (1984). Caring. A feminine approach to ethics and moral education. Berkeley: Univ. of California Press.

Noddings, N. (2005). Educating Citizens for Global Awareness. New York: Teacher's College Press. 
Nordberg, M. (2005). ”Det viktiga är en maskulin touche!” - Maskulinitet som konsumtionsvara i frisörbranschen. Kulturella Perspektiv svensk etnologisk tidskrift, 14(3).

Nylund, M. (2013). Yrkesutbildning, klass och kunskap: en studie om sociala och politiska implikationer av innehållets organisering i yrkesorienterad utbildning med fokus på 2011 års gymnasiereform. Diss. (summary) Örebro: Örebro University.

Nyström, A. (2012). Att synas och lära utan att synas lära: en studie om underprestation och privilegierade unga mäns identitetsförhandlingar $i$ gymnasieskolan. Diss. Uppsala: Uppsala University.

Owens, T. (2000). Men on the Move: a study of barriers to male participation in education and training initiatives. Dublin: Aontas.

Paldanius, S. (2002). Ointressets rationalitet: om svårigheter att rekrytera arbetslösa till vuxenstudier. Diss. Linköping: Univ.

Patton, P. (1979). Of power and prisons. In M. Morris \& P. Patton (eds.), Michel Foucault, Power/Truth/Strategy (pp. 109-146). Sydney: Feral Publications.

Pierce, J. L. (1995). Gender Trials: Emotional lives in contemporary law firms. Berkeley: Univ. of California Press.

Potter, J. \& Wetherell, M. (1987). Discourse and Social Psychology: beyond attitudes and behaviour. London: Sage.

Ramazanoğlu, C. (red.) (1993). Up Against Foucault. Explorations of some tensions between Foucault and feminism, Routledge.

Ramazanoğlu, C. and Holland, J. (2002). Feminist Methodology: challenges and choices. London: SAGE Publications.

Rose, H. (1994). Love, Power and Knowledge: Towards a feminist transformation of the sciences. Bloomington and Indianapolis: Indiana Univ. Press.

Rose, N. (1996). The death of the social? Re-figuring the territory of government. Economy and Society, 25(3): 327-356.

Rose, N. (1999a). Powers of Freedom: reframing political thought. Cambridge: Cambridge Univ. Press.

Rose, N. (1999b). Inventiveness in politics. Economy and Society, 28(3): 467493.

Rubenson, K. (1975). Rekrytering till vuxenutbildning: en studie av kortutbildade yngre män. Diss. Gothenburg: Univ.

Ryan, G.W., \& Bernard, H. R. (2003). Techniques to Identify Themes. Field Methods, 15 (1): 85-109. doi:10.1177/1525822X02239569.

Sandell, A. (2007). Utbildningssegregation och självsortering. Om gymnasieval, genus och lokala praktiker. Malmö: Malmö Studies in Educational Sciences 31.

Schensul, S. L., Schensul, J. J. \& LeCompte, M. D. (1999). Ethnographer's Toolkit 2 Essential ethnographic methods: observations, interviews, and questionnaires. Walnut Creek, Calif: AltaMira.

Scranton, P. (ed.) (2001). Beauty and Business: commerce, gender, and culture in modern America. New York: Routledge. 
Seymour, D. (2000). Emotional Labour: A comparison between fast food and traditional service work. Hospitality Management, 19: 159-171.

Sheridan, A. (1980). Michel Foucault: The will to truth. New York: Tavistock.

Skeggs, B. (1997). Formations of Class and Gender: becoming respectable. London: Sage.

Smith, P. (1992). The Emotional Labour of Nursing. Macmillan: London.

Somerville, M. \& Abrahamsson, L. (2003). Trainers and workers constructing a community of practice: masculine work cultures and learning safety in the mining industry. Studies in the Education of Adults, 15(1), 19-35.

Somerville, M. (2005). Working culture: expanding notions of workplace cultures and learning at work. Pedagogy, Culture and Society, 13(1), 5-27.

Somerville, M. (2006). Becoming-worker: vocational training for workers in aged care. Journal of Vocational Education and Training, 58(4): 471-481.

SOU 2004:43. Den könsuppdelade arbetsmarknaden. Stockholm: Fritzes förlag.

SOU 2008:27. Gymnasieutredningen, 2008. Framtidsvägen - en reformerad gymnasieskola: betäkande. Stockholm: Fritze.

SOU 2015:100. Skönhetsutredningen, 2015. Kroppsbehandlingar. Åtgärder för ett stärkt konsumentskydd. Stockholm.

Statistics Sweden (2018) About us. Retrieved from http://www.scb.se/en/Aboutus/

Steno, A.M. \& Friche, N. (2015). Celebrity chefs and masculinities among male cookery trainees in vocational education. Journal of Vocational Education and Training, 67(1): 47-61.

Steinberg, R. J. \& Figart, D. M. (1999). Emotional labour since The Managed Heart. The Annals of the American Academy 561: 8-26.

Stenross, B. \& Kleinman, S. (1989). The highs and lows of emotional labour:

Detectives' encounters with criminals and victims. Journal of

Contemporary Ethnography, 17(4): 435-452.

Swedish National Agency for Education (2018). Skolor och elever $i$ gymnasieskolan läsår 2017/18. Elever på program redovisade efter typ av huvudman och kön, tabell 5A. Retrieved from:

https://www.skolverket.se/statistik-och-utvardering/statistik-itabeller/gymnasieskola/skolor-och-elever

Swedish National Agency for Higher Vocational Education (2018). Statistisk årsrapport 2018. Retrieved from

https://www.myh.se/Documents/Publikationer/Rapporter/2018/Statistisk arsrapport2018.pdf

Taylor, A., Hamm, Z. \& Raykov, M. (2015). The experiences of female youth apprentices in Canada: just passing through? Journal of Vocational Education and Training, (67)1: 93-108.

Theodosius, C. (2008). Emotional labour in health care: the unmanaged heart of nursing. Abingdon: Routledge.

The National Board of Health and Welfare (2013). Press release: Socialstyrelsen vill reglera skönhetsbranschen. Retrieved from

http://www.socialstyrelsen.se/nyheter/2013juli/socialstyrelsenvillreglerask onhetsbranschen 
The Swedish National Organisation for Skin Therapists (2015).

Hudvårdsbranschen 2015. Retrieved from

http://www.shr.nu/sites/default/files/branschrapportSHR2015.pdf

Toerien, M. \& Kitzinger, C. (2007). Emotional labour in action: Navigating multiple involvements in the beauty salons. Sociology, 41: 645-662.

Totterdell, P., \& Holman, D. (2003). Emotion regulation in customer service roles: Testing a model of emotional labor. Journal of Occupational Health Psychology, 8(1): 55-73.

Vetenskapsrådet, (2002). Forskningsetiska principer inom humanistisksamhällsvetenskaplig forskning. Stockholm: Vetenskapsrådet.

Waerness, K. (1996). The Rationality of Caring. In S. Gordon, P. Benner \& N. Noddings (eds.), Caregiving: readings in knowledge, practice, ethics, and politics (pp. 231-256). Philadelphia, Pa.: Univ. of Pennsylvania Press.

Warin, J. \& Gannerud, E. (2014). Gender, teaching and care: a comparative global conversation. Gender \& Education, 26(3): 193-199.

Waring, A. (2008). Health club use and lifestyle: exploring the boundaries between work and leisure. Leisure Studies, 27(3): 295-309.

Weedon, C. (1997). Feminist practice and poststructural theory (2nd ed.). Oxford. UK: Blackwell.

Westerberg, K. \& Hjelte, J. (2013). The impact of elderly care competence and quality improvement programme in four Swedish municipalities. Journal of Vocational Education and Training, 65(3): 319-332.

Wetterer, A. (ed.) (1995). Die Soziale Konstruktion Von Geschlecht in Professionalisirungs-prozessen (The social construction of gender in processes of professionalization). Frankfurt: Campus.

Winther Jørgensen, M. \& Phillips, L. (2000). Diskursanalys som teori och metod. Lund: Studentlitteratur.

Wolf, N. (1991). The Beauty Myth. London: Virago. 


\section{APPENDIX: INTERVIEW GUIDE FOR STUDENTS IN SKIN AND SPA THERAPY EDUCATION AND TRAINING}

How did you decide to come here?

- Educational experience

- Work experience

- Previous ideas about this vocation and the school

- Plans and dreams for the future

What do you (all) do here at this school?

- How would you describe this education and training for someone who does not know anything about it?

- Lessons/subjects/practice

- Other activities

- What is the purpose?

What characterizes a good and successful teacher here at the school?

- Disposition/personality

- Skills/behaviour

- Teaching style/arrangement

- What do you learn from a good teacher?

What characterizes a good and successful student here at the school?

- Disposition/personality

- Skills/behaviour

- When are you complimented and/or encouraged?

- When are you criticized?

What characterizes a good and successful skin and spa therapist?

- Disposition/personality

- Skills/behaviour

- Where do you see yourself in the industry in the future? 


\section{Papers}

The papers associated with this thesis have been removed for copyright reasons. For more details about these see:

http://urn.kb.se/resolve?urn=urn:nbn:se:liu:diva-150953 


\section{LINKÖPING STUDIES IN BEHAVIOURAL SCIENCE}

184. GRADIN FRANZÈN, ANNA. Disciplining freedom: Treatment dilemmas and subjectivity at a detention home for young men. 2014. ISBN: 978-91-7519-344-1

185. ENGSTRÖM, ANNIKA. Lärande samspel för effektivitet. En studie av arbetsgrupper i ett mindre industriföretag. 2014. ISBN:978-91-7519-345-8

186. ELWÉR, ÅSA. Early Predictors of Reading Comprehension Difficulties. 2014. ISBN: 978-91-7519281-9

187. LARSON, NICLAS. Matematikämnet och stadiebytet mellan grundskolan och gymnasieskolan. En enkät- och klassrumsstudie. 2014. ISBN: 978-91-7519-196-6

188. LY, HOA. Use of a Smartphone Application in the Treatment of Depression - The New Wave of Digital Tools for Psychological Treatment. 2015. ISBN: 978-91-7519-136-2

189. HANSSON, PER-OLOF. New ways of learning. Participatory action research and Kenyan runners' appropriation of smartphones to improve their daily lives and participation in m-learning. 2015. ISBN: 978-91-7519-124-9

190. BOLLDÈN, KARIN. Online teaching practices. Sociomaterial matters in higher education settings. 2015. ISBN: 978-91-7519-123-2

191. MALMQUIST, ANNA. Pride and Prejudice. Lesbian families in contemporary Sweden. 2015. ISBN: 978-91-7519-087-7

192. AVBY, GUNILLA. Evidence in Practice. On Knowledge Use and Learning in Social Work. 2015. ISBN: 978-91-74519-088-4

193. FORSBERG, CAMILLA. Students’'Perspectives on Bullying. 2016. ISBN: 978-91-7685-874-5

194. MUHRMAN, KAROLINA. Inget klöver utan matematik. En studie av matematik i yrkesutbildning och yrkesliv. 2016. ISBN: 978-91-7685-851-6

195. SKAGERLUND, KENNY. Magnitude Processing in Developmental Dyscalculia. A Heterogeneous learning disability with different cognitive profiles. 2016. ISBN: 978-91-7685-831-8

196. EKEBLAD, ANNIKA. A Randomized Trial of Interpersonal Psychotherapy and Cognitive Behavioral Therapy for Major Depressive Disorder - Predictors of process and outcome. 2016. ISBN: 978-91-7685-803-5

197. MÅNSSON, KRISTOFFER N.T. Restructuring the Socially Anxious Brain. Using magnetic resonance imaging to advance our understanding of effective cognitive behaviour therapy for social anxiety disorder. 2016. ISBN: 978-91-7685-688-8

198. SILFVERNAGEL, KRISTIN. Individually tailored internet-based cognitive behavioural therapy for adolescents, young adults and older adults with anxiety. 2017. ISBN: 978-91-7685-566-9

199. ELOFSSON, JESSICA. Children's early mathematics learning and development. Number game interventions and number line estimations. 2017. ISBN: 978-91-7685-517-1

200. ÅHLFELDT, EMANUEL. Hållbart utvecklingsarbete i vård och omsorg. Ett institutionellt perspektiv på projekt i en professionell och byråkratisk kontext. 2017. ISBN: 978-91-7685-445-7 
201. VERNMARK, KRISTOFER. Therapeutic alliance and different treatment formats when delivering internet-based CBT for depression. 2017. ISBN: 978-91-7685-436-5

202. FRANKL, MY. Psychotherapy for Substance Use Disorder - the importance of affects. 2017. ISBN: 978-91-7685-429-7

203. ABDULLA, AFRAH. Readiness or resistance? - Newly arrived adult migrants' experiences, meaning making, and learning in Sweden. 2017. ISBN: 978-91-7685-428-0

204. OLSSON, LINDA. “Count on me!”. Mathematical development, developmental dyscalculia and computer-based intervention. 2018. ISBN: 978-91-7685-409-9

205. COLLIANDER, HELENA, Being and Becoming a Teacher in Initial Literacy and Second Language Education for Adults. 2018. ISBN: 978-91-7685-304-7

206. TOPOOCO, NAIRA. Blended Cognitive Behavior Therapy. Efficacy and Acceptability for Treating Depression in the Adult and Adolescent Population. 2018. ISBN: 978-91-7685-297-2

207. SOLÍS MARCOS, IGNACIO. Challenges in Partially Automated Driving: A Human Factors Perspective. 2018. ISBN: 978-91-7685-296-5

208 THORSTEN, ANJA. Berättelseskrivande i skolan. Att studera, beskriva och utveckla ett kunnande. 2018. ISBN: 978-91-7685-258-3 